\title{
Lithospheric structure and geodynamics at the northern margin of Tibetan plateau*
}

\author{
Junmeng Zhao ${ }^{1,2, *}$ Fang $\mathrm{Lu}^{3} \quad$ Zhichun $\mathrm{Li}^{4} \quad$ Yang Wang ${ }^{5}$ \\ Wentao $\mathrm{Ma}^{2}$ and Xun Liu \\ ${ }^{1}$ Key Laboratory of Continental Collision and Plateau Uplift, Institute of Tibetan Plateau Research, \\ Chinese Academy of Sciences, Beijing 100101, China \\ ${ }^{2}$ Institute of Geology, China Earthquake Administration, Beijing 100029, China \\ ${ }^{3}$ Earthquake Administration of Hubei Province, Wuhan 430071, China \\ ${ }^{4}$ Institute of Occupational Disease Protection for Laboring Hygiene of Hunan Province, \\ Changsha 410007, China \\ ${ }^{5}$ School of Earth Sciences and Resources, China University of Geosciences, Beijing 100083, China \\ ${ }^{6}$ Institute of Geology, Chinese Academy of Geological Sciences, Beijing 100037, China
}

\begin{abstract}
A recent integrated geophysical survey has been completed along a transect from Baicheng, Xinjiang to Da Qaidam, Qinghai, China. In this study, wide-angle seismic reflection/refraction exploration with 10 shot points has been carried out to acquire the velocity structure of the crust and uppermost mantle. The earthquake focal mechanism solutions and terrestrial heat flow along the transect have also been obtained and analyzed. Based on the velocity structure of the crust and uppermost mantle along the transect, and combined with the focal mechanism solutions and terrestrial heat flow we develop a geodynamic model for the northern margin of the Tibetan plateau. This model reveals the detailed structure of the crust and uppermost mantle, determines the relationship of basin and range coupling, explores the deep dynamic setting for superposed basins, and establishes the northern boundary condition for Tibetan plateau research.
\end{abstract}

Key words: Tarim basin; Altyn Tagh; Qaidam basin; Tibetan plateau; geodynamic model

CLC number: P315.2 Document code: A

\section{Introduction}

The Altay orogen, Junggar basin, Tianshan orogen, Tarim basin, Altyn Tagh orogen, Qaidam basin and the Kunlun orogen compose a large-scale basin and range tectonic province, in northwestern China (Zhao, 2005). This system lies along the northern margin of the Tibetan plateau, and, therefore, serves as an important region for studying the uplift mechanism of the Tibetan plateau. In a larger scope, this system is located in the backland of central Asia, which is a crucial region for understanding the geodynamics of central Asia and the

\footnotetext{
* Received 11 October 2012; accepted in revised form 20 November 2012; published 10 December 2012.

† Corresponding author. e-mail: zhaojm@itpcas.ac.cn

(c) The Seismological Society of China, Institute of Geophysics,

China Earthquake Administration, and Springer-Verlag Berlin Heidelberg 2012
}

world as a whole. In addition, this region is of significant economic value being characterized by abundant sources of oil, natural gases, and metallic resources. Unfortunately, this region is also prone to serious draught, frequent earthquakes, and environment changes, which pose a threat to life and property located in the region.

Over the past few decades, a significant amount of geophysical research has been conducted in order to examine the detailed structure of the crust and uppermost mantle beneath the Tianshan (Poupinet et al., 2002; Zhao et al., 2003b; Wang et al., 2004a), the Tarim basin (Shao et al., 1996; Zhao et al., 2006), the Altyn Tagh mountains (Wittlinger et al., 1998; Xu et al., 1999) and the Qaidam basin (Zhu and Helmberger, 1998; Gao et al., 1999). Supported by the Chinese National Key Basic Research Program (G1999043301), an integrated geophysical survey was completed along a transect between Baicheng, Xinjiang and Da Qaidam, 
Qinghai (Figure 1). Along the transect, wide-angle seismic reflection/refraction exploration with 10 shot points was carried out to acquire $\mathrm{P}$ and $\mathrm{S}$ wave velocities (Zhao et al., 2006, 2008, 2012), $Q$ values (Zhao et al., 2003c), and Poisson's and velocity ratios (Zhao et al., 2012). Density and magnetization intensity structures are determined by joint inversion of gravity and magnetism (Zhao et al., 2003c, 2004a), which enables us to compile a global geoscience transect (GGT) (Zhao et al., 2010).
The transect begins at Baicheng near the northern margin of the Tarim basin $\left(42^{\circ} 10^{\prime} \mathrm{N}, 80^{\circ} 36^{\prime} 35.1^{\prime \prime} \mathrm{E}\right)$ and extends southeastward to Da Qaidam at the eastern edge of the Qaidam basin $\left(37^{\circ} 48^{\prime} 38.9^{\prime \prime} \mathrm{N}, 95^{\circ} 59^{\prime} 18.6^{\prime \prime} \mathrm{E}\right)$. This paper proposes a geodynamic model for the northern margin of the Tibetan plateau, based on the combined results of the velocity structure and focal mechanism solutions of earthquakes as well as terrestrial heat flow along the transect.

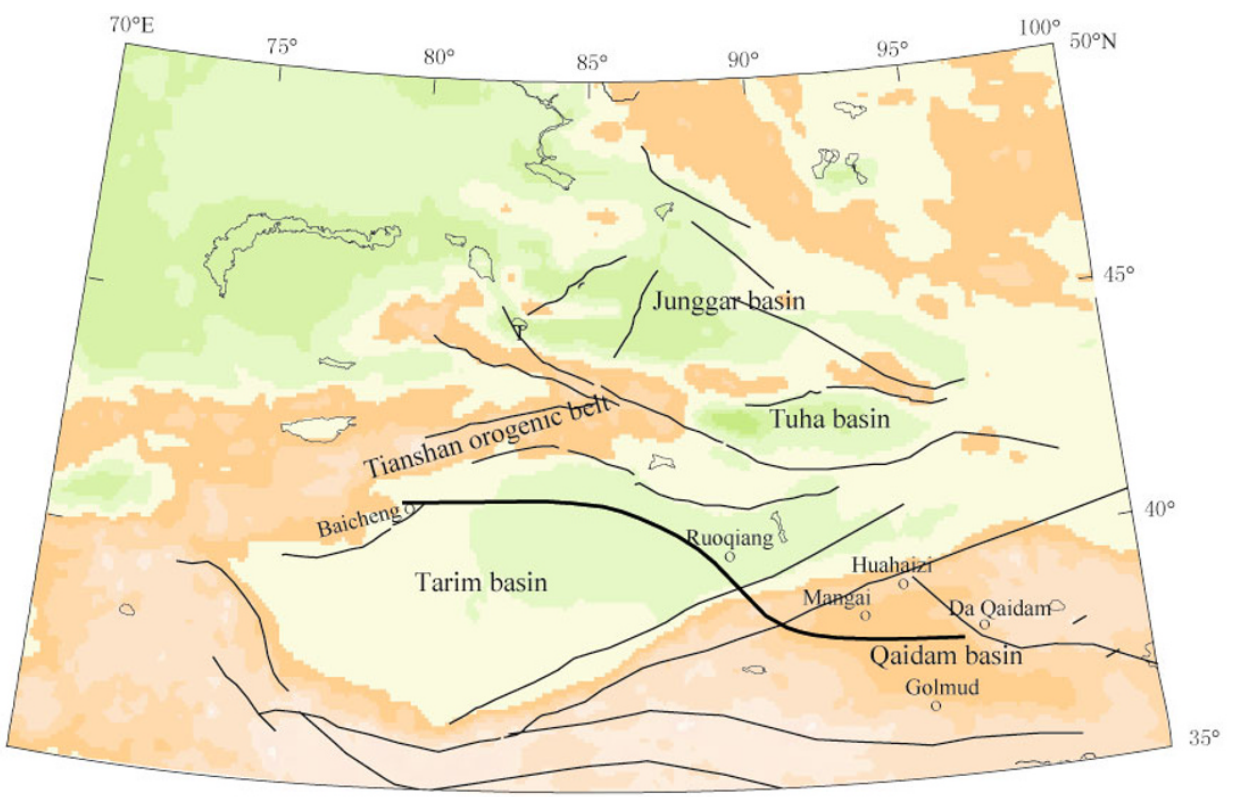

Figure 1 Location of geoscience transect from Baicheng, Xinjiang to Da Qaidam, Qinghai.

\section{Geological background}

From east to west, the GGT crosses the southern Tianshan, the northern Tarim basin, the Altyn Tagh, and the Qaidam basin. The southern margin of Tianshan has grown southward into the Tarim basin, generating a $\sim 500 \mathrm{~km}$-wide nappe zone. This region consists of a series of thrust faults, including the range-front faults along the southern Tianshan, which have stacked a series of imbricate rock sheets on the Mesozoic and Cenozoic strata of the Tarim basin (Zhao et al., 2010). The basement of the Tarim basin looks like a gentle structure, which resembles the covers of the Paleozoic, Mesozoic and Cenozoic strata in fold deformation, and has few faults. However, several major seismically active faults are present, including the the Tianshan rangefront fault, which has exhibited apparent right-lateral strike-slip displacement.

The Altyn Tagh mountains are characterized by well-exposed Precambrian strata that are intruded by significant quantities of Precambrian and Paleozoic igneous rocks. The well-defined Altyn Tagh fault governs the distribution of strata, the location of magmatic activity, and the deformation in this area (Bendick et al., 2000; Wang et al., 2004b). In particular, the left-lateral strike-slip displacement of the Altyn Tagh fault controls the distribution of Mesozoic and Cenozoic sediments on either side of the fault.

The Qaidam basin is a large intermontane sedimentary basin (Liu and Gao, 1998), where abundant oil and gas resources have been discovered (Wang et al., 2004b). The formation of the modern Qaidam basin began in the Mid-Eocene following the onset of the collision between Indian and Eurasian plates (Molnar and Tapponnier, 1975). Field-based geological studies have shown that the area around the Qaidam basin experienced pronounced thrust faulting, uplift and erosion, and large-scale strike-slip motion along the Altyn Tagh fault (Molnar and Tapponnier, 1975; Peltzer and Tapponnier, 1988; Tapponnier et al., 1990, 2001; Meyer et 
al., 1998; Métivier et al., 1998; Ritts et al., 2004).

Along its northwestern margin, the Qaidam basin is separated from the Altyn Tagh range by the leftlateral Altyn Tagh strike-slip fault (Figure 1), which has a total estimated offset of 300-500 km (Peltzer and Tapponnier, 1988; Ritts and Biffi, 2000; Cowgill et al., 2003). The Qaidam basin is bound to the south by a southwest-dipping thrust belt. The northernmost fault in the thrust belt is the Qiman Tagh fault, while the North Kunlun thrust delineates the southernmost fault in the thrust belt (Figure 1). The thrust belt is characterized by Proterozoic metamorphic rocks and Paleozoic sedimentary and igneous rocks that structurally overlie Tertiary strata (Bally et al., 1986). Detailed seismic reflection profiles, drilling data, stratigraphic records, and field mapping indicate that the Qiman Tagh and North Kunlun thrusts have been active since the Early Pliocene. The fault systems are currently active (Song and Wang, 1993) and accommodate north-south shortening. The northeastern margin of the Qaidam basin is delineated by the north-dipping Qaibeiyuan thrust belt, which separates the basin from the Qilianshan and also places high-grade Proterozoic metamorphic rocks on Cenozoic sedimentary rocks.

\section{Velocity structure of crust and uppermost mantle and geologi- cal interpretation}

Along the Baicheng-Da Qaidam transect (Figure 1), a wide-angle seismic reflection/refraction survey was conducted. This survey included 10 shot points: Baicheng (1 299.7), Kuqa (1 209.9), Luntai (1 129.5), Korla (1 008.7), Yuli (906.2), Ruoqiang (743.9), Xiaokelihu (621.2), Youshashan (474.6), Laomangai (420.5), and Da Qaidam (110.2). A combined-well explosion with 2 tons of TNT was implemented at each shot point, and 300 sets of high-precision three-component seismometers were used to record the signals. The observation system and shot point parameters are shown in Figure 2 and Table 1, and the seismic records observed in Xiaokelihu shot point are shown in Figure 3 . Assuming two-dimensional (2D) lateral heterogeneity, ray tracing and theoretical seismography were conducted (Figure 4), and a 2D velocity structure was obtained (Figure 5).

In the area covered with dense seismic rays (confined by white dashed line), the $\mathrm{P}$ wave velocity model is convincing and has been shown to have an uncertainty of 3\% (Zhao et al., 2006). The velocity structure outside this area has been extrapolated. Along most of the profile shown in Figure 5, the crust has been vertically divided into upper, middle, and lower. However, beneath the Qaidam basin, the lower crust is divided into only two layers separated by an interface. In general, the upper crust is defined by the velocities $v_{\mathrm{P}}<6.4 \mathrm{~km} / \mathrm{s}$, and a basal depth of $18-21 \mathrm{~km}$, the middle crust is defined by velocities between $6.4-6.7 \mathrm{~km} / \mathrm{s}$, and a basal depth of $32-40 \mathrm{~km}$, and the lower crust is defined by velocities between $6.7-7.0 \mathrm{~km} / \mathrm{s}$ and having a highly undulatory base (Moho discontinuity) at a depth of $40-55 \mathrm{~km}$. The velocity of the uppermost mantle is $v_{\mathrm{P}}>7.0 \mathrm{~km} / \mathrm{s}$. Based

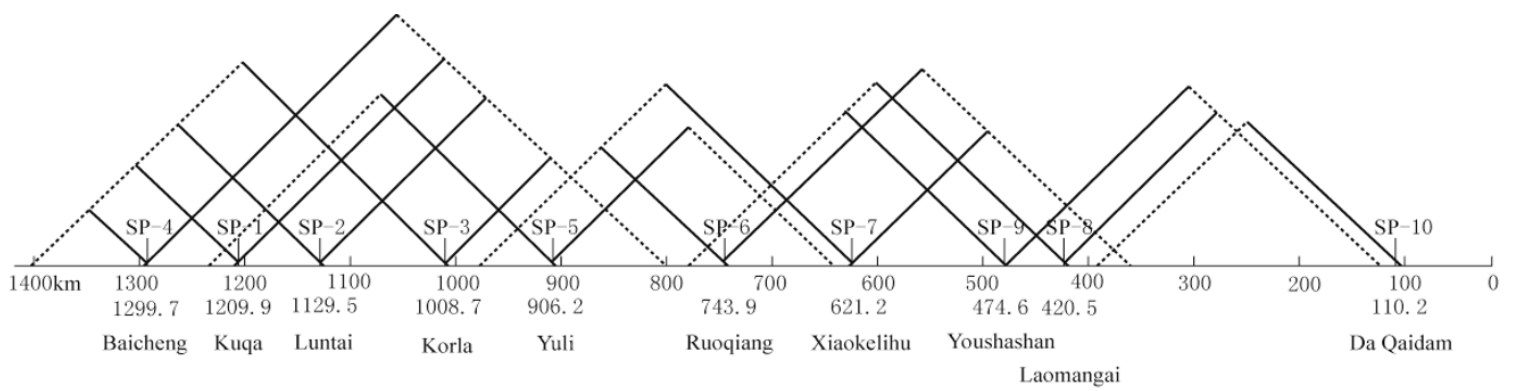

(a)

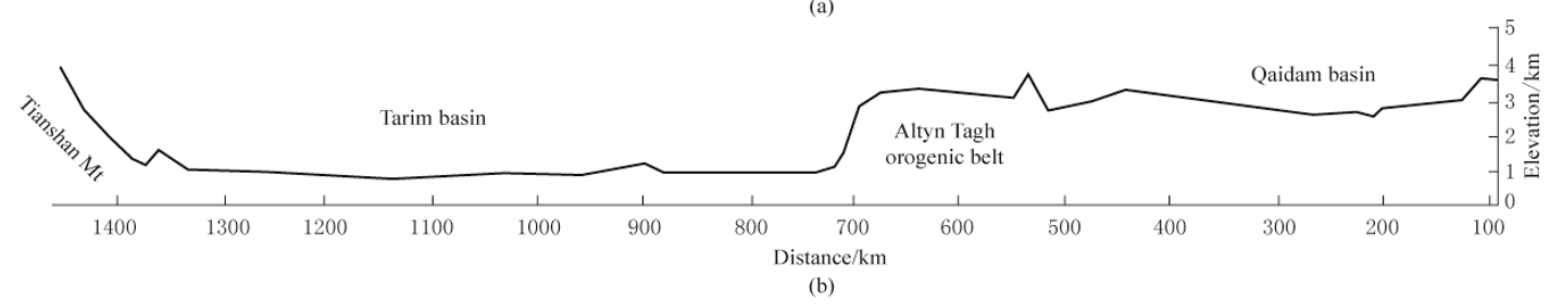

Figure 2 Observational system for the Baicheng-Da Qaidam transect. (a) Observational system; (b) Elevation profile along the transect. 


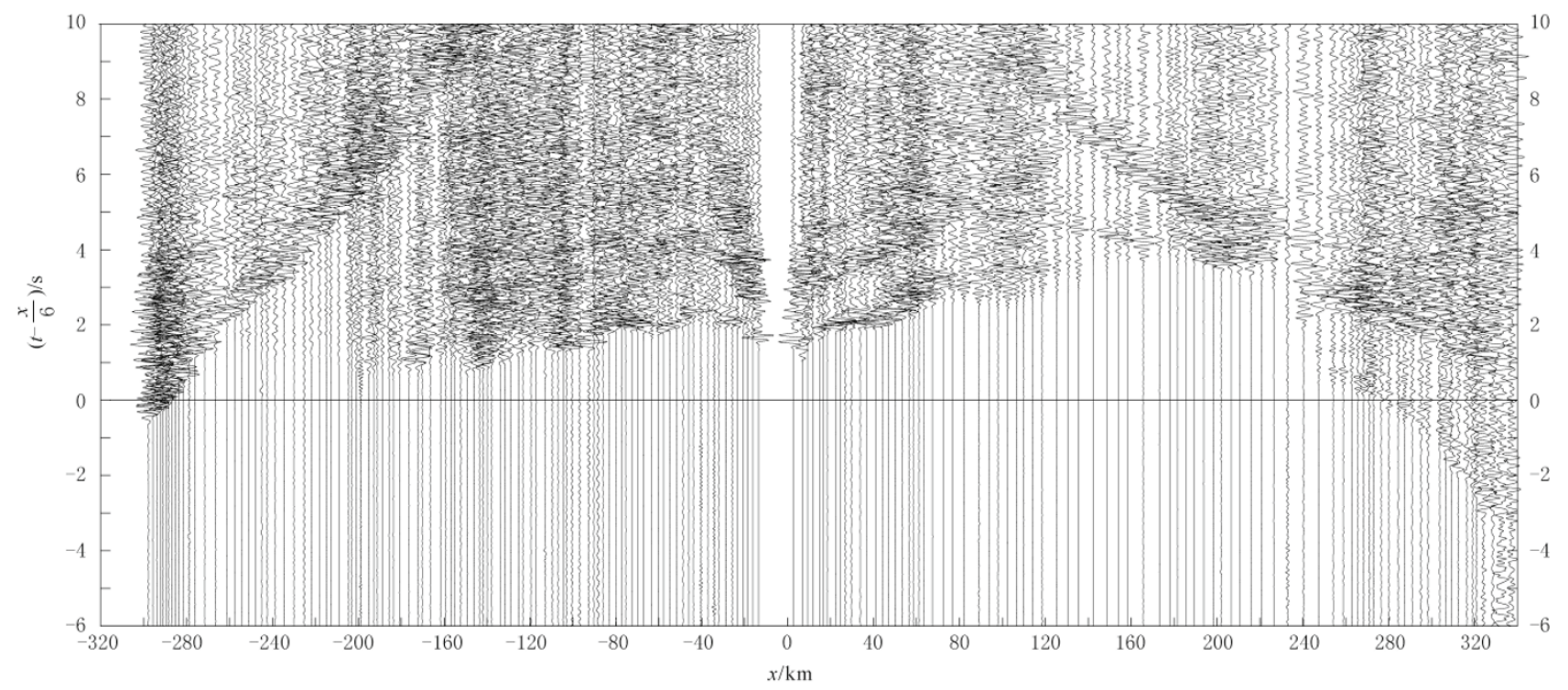

Figure 3 Observed seismic records of the Xiaokelihu shot point (SP474.6). The vertical axis indicates travel time reduced by $6 \mathrm{~km} / \mathrm{s}$. The horizontal axis indicates offset distance $(x)$ from the shot point. A 1-20 Hz bandpass filter and automatic gain control with $2 \mathrm{~s}$ window were applied.
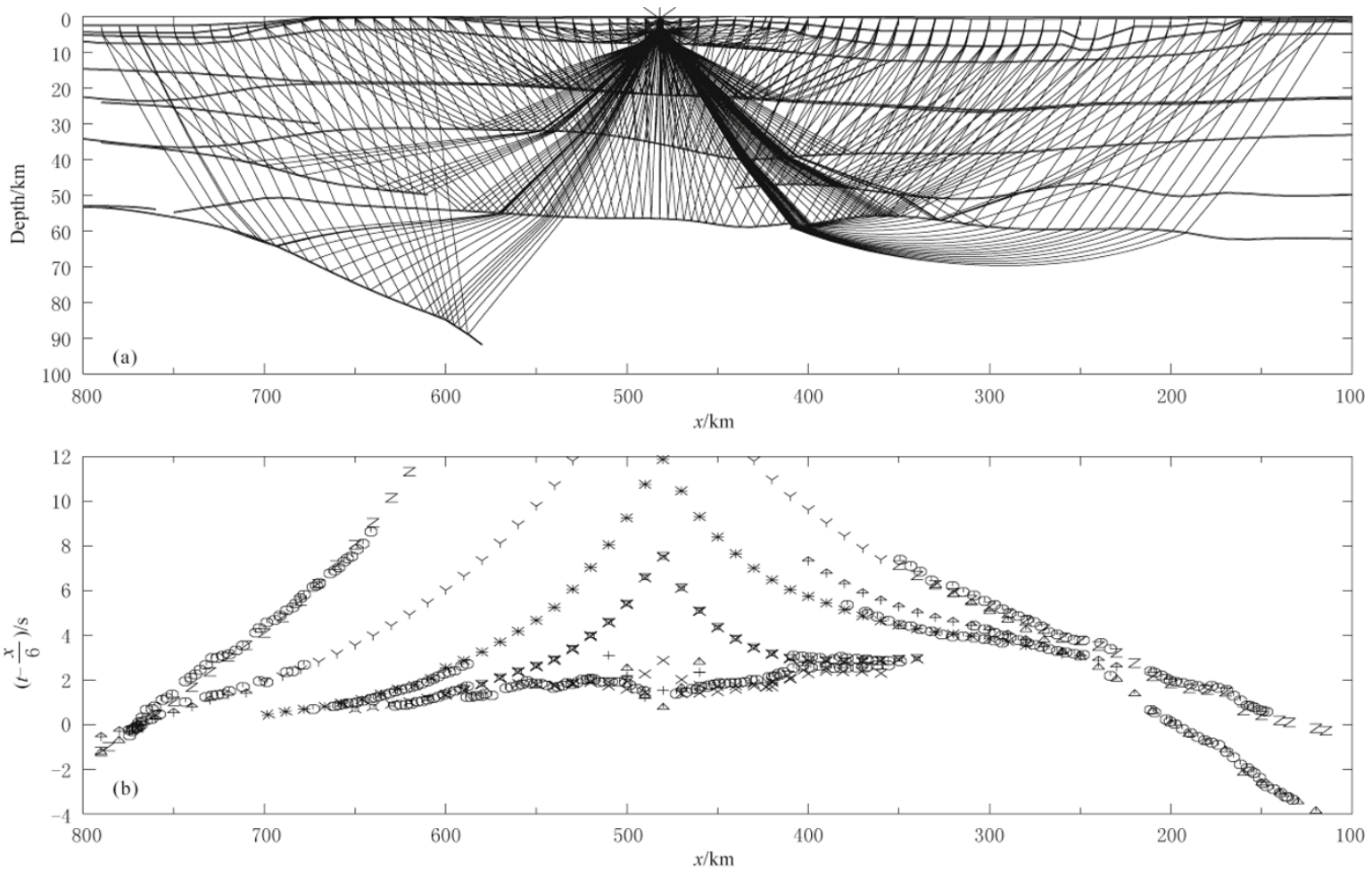

Figure 4 Modeling example for the Xiaokelihu shot point (SP474.6). The shot point (at $0 \mathrm{~km})$ is located in the Tarim basin (c.f. Figure 1). The receivers were located in the Tarim basin, the Altyn Tagh range and the Qaidam basin. (a) Ray tracing. The vertical axis shows depth in $\mathrm{km}$. The horizontal axis shows offset distance $(x)$ from the shot point. The thick lines are interfaces determined by modeling of the seismic phases. (b) Travel time fitting: The vertical axis shows travel time measured (marked with $($ ) ) and calculated (with other marks), reduced by $6 \mathrm{~km} / \mathrm{s}$. Travel times of all observed phases constitute the input data for ray tracing and synthetic seismogram. 


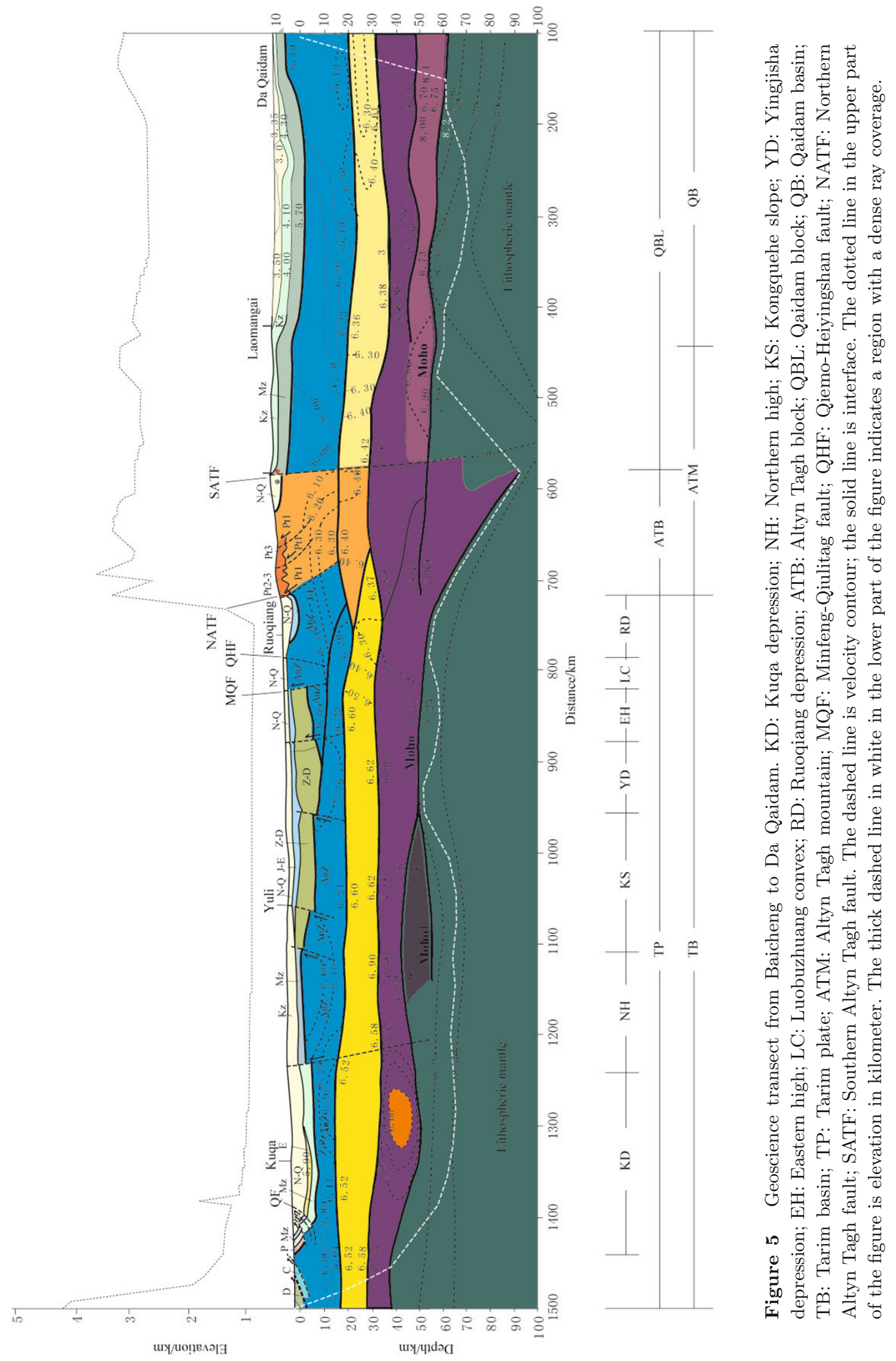


Table 1 Shot point parameters for the Baicheng-Da Qaidam profile

\begin{tabular}{|c|c|c|c|c|c|}
\hline $\begin{array}{c}\text { No. of } \\
\text { shotting }\end{array}$ & $\begin{array}{l}\text { Location of } \\
\text { shot point }\end{array}$ & $\begin{array}{c}\text { Shot point stake } \\
\text { number } / \mathrm{km}\end{array}$ & Shotting time & $\begin{array}{l}\text { Number of } \\
\text { records }\end{array}$ & $\begin{array}{c}\text { Range of } \\
\text { observation } / \mathrm{km}\end{array}$ \\
\hline 1 & Kuqa & 1299.7 & May $30,01 \mathrm{~h} 30 \mathrm{~min} 6.75 \mathrm{~s}$ & 197 & $804.2-1500.0$ \\
\hline 2 & Luntai & 1129.5 & May $30,02 \mathrm{~h} 00 \mathrm{~min} 7.35 \mathrm{~s}$ & 197 & $804.2-1500.0$ \\
\hline 3 & Korla & 1008.7 & May 30, 02h30min5.96s & 197 & $804.2-1500.0$ \\
\hline 4 & Baicheng & 1299.7 & May $30,03 \mathrm{~h} 00 \mathrm{~min} 7.07 \mathrm{~s}$ & 197 & $804.2-1500.0$ \\
\hline 5 & Yuli & 906.2 & June $4,01 \mathrm{~h} 00 \mathrm{~min} 7.03 \mathrm{~s}$ & 197 & $738.2-1234.8$ \\
\hline 6 & Ruoqiang & 743.9 & June $10,01 \mathrm{~h} 30 \mathrm{~min} 6.48 \mathrm{~s}$ & 197 & $361.5-907.0$ \\
\hline 7 & Xiaokelihu & 621.2 & June $10,02 \mathrm{~h} 00 \mathrm{~min} 6.36 \mathrm{~s}$ & 197 & $361.5-907.0$ \\
\hline 8 & Lao mangai & 420.5 & June $15,01 \mathrm{~h} 30 \mathrm{~min} 7.15 \mathrm{~s}$ & 197 & $127.7-745.8$ \\
\hline 9 & Youshashan & 474.6 & June $15,02 \mathrm{~h} 00 \mathrm{~min} 6.65 \mathrm{~s}$ & 197 & $127.7-743.0$ \\
\hline 10 & Da Qaidam & 110.2 & June $20,02 \mathrm{~h} 00 \mathrm{~min} 7.49 \mathrm{~s}$ & 65 & $101.5-372.0$ \\
\hline
\end{tabular}

on distinct features and crustal structure, the profile can be divided laterally into three regions: the Tarim basin, the Altyn Tagh orogen and the Qaidam basin.

\subsection{Tarim basin}

The Tarim basin has a fairly thick sediment cover, which exceeds $10 \mathrm{~km}$ in front of the South Tianshan and in the Kuqa depression. The crust of Kuqa is somewhat complicated, having a relatively thin upper crust and a thick middle and lower crust, with large-scale lowvelocity layers in which velocity decreases by $0.35 \mathrm{~km} / \mathrm{s}$. In addition, the Moho discontinuity bends downward intensively beneath the Kuqa depression. The doubleMoho appears between Luntai and Korla, which looks like a "Y" shape diminishing eastward nearby Yuli. The medium velocity between the two Moho discontinuities is greater than that of the lower crust and less than that of the uppermost mantle.

Several interpretations have been proposed to explain the phenomenon discussed above. The first suggests that the material from upper mantle generates a chamber between the crust and mantle. However, the relatively low velocity of this area does not support an upper mantle source, thereby this interpretation is rejected. The second assumes that there is a fault that cuts the Moho in front of the South Tianshan, and that the Baicheng-Da Qaidam profile crosses this fault, and results in travel-time curves of the double-Moho. To test this possibility, forward modeling calculations were performed on models of normal and thrust faults (Zhao, 2012). The test result showed that neither normal nor thrust faulting of the Moho could produce travel-time curves of the double-Moho structure, implying that the double-Moho beneath Kuqa is not the consequence of Moho offset. A third explanation suggests that between Luntai and Korla, in the northern Tarim basin, there is a nearly NS-striking structural zone that partitions the basin into two tectonic regions (Zhao, 2012), where underthrusting of the Tarim basin beneath the Tianshan orogen occurs at different rates. Let's assume that the rate of underthrusting beneath the western region is faster than that of the eastern region. Thus the western Tarim basin has moved to the north a greater distance, and therefore is closer to the Tianshan with respect to the eastern Tarim. Because the profile bends southeastward after crossing the distance between Luntai and Korla above where the double Moho is prominent, the lower underthrusting rate to the east results in an eastward narrowing of the double-Moho region until it pinches out beneath the Tarim basin. At present, this explanation is only speculative due to a lack of supporting data.

The crust and uppermost mantle compositions can be determined from seismic wave velocity and their relation to rock types determined by laboratory experiments (Christensen and Mooney, 1995). The crust consists of six layers from sediment cover to mafic rocks (Figure 5). Below the crust there may be mixed material $\left(v_{\mathrm{P}}=7.3-7.8 \mathrm{~km} / \mathrm{s}\right)$ of mafic crust and ultramafic mantle as well as ultramafic mantle rock $\left(v_{\mathrm{P}}>7.8 \mathrm{~km} / \mathrm{s}\right)$. The near surface layer is composed of sediments and crystalline basement rocks with velocity $4.6-5.7 \mathrm{~km} / \mathrm{s}$. The upper crust has a stable velocity of $6.0-6.2 \mathrm{~km} / \mathrm{s}$.

North of the Che'erchen fault, $100 \mathrm{~km}$ north of the Altyn Tagh fault, it is suggested that the middle crust $\left(v_{\mathrm{P}}=6.6 \mathrm{~km} / \mathrm{s}\right)$ and lower crust $\left(v_{\mathrm{P}}=6.9-7.25 \mathrm{~km} / \mathrm{s}\right)$ are composed of intermediate and mafic rocks. South of the Che'erchen fault, below the Altyn Tagh orogen and Qaidam basin, the velocity of the middle crust decreases to $6.3-6.4 \mathrm{~km} / \mathrm{s}$, and the velocity of the lower crust is $6.6-6.8 \mathrm{~km} / \mathrm{s}$, suggesting a mafic and intermediate rock composition.

\subsection{Altyn Tagh orogen}

Wittlinger et al. (1998) assumed that the entire Tarim basin crust underthrusts beneath the Altyn Tagh 
orogen, which results in crustal thickness up to $90 \mathrm{~km}$. However, our velocity structure does not support this model in some features. (1) The crustal thickness of the Tarim basin is $48 \mathrm{~km}$, while that of the Altyn Tagh orogen is $53 \mathrm{~km}$, a difference of $5 \mathrm{~km}$, which excludes the possibility of a double-layered crust. (2) The wedgeshape low-velocity body means a mix of materials from mafic lower crust and ultramafic upper mantle, which is contradictory to underthrusting of the entire crust. (3) Approximately $100 \mathrm{~km}$ north of the Altyn Tagh orogen, the middle and lower crustal compositions change dramatically (Zhao et al., 2006), suggesting that it is not possible that the lower crust of the Tarim basin moves in a southeastward direction downward beneath the Altyn Tagh orogen. If underthrusting of the Tarim basin produces the mix of mafic crust and ultramafic mantle, the mafic lower-crustal material should have extended to the wedge-shaped low-velocity body below the Altyn Tagh orogen and should be observable. There is, however, no such evidence from our seismic data to support this interpretation.

Our research shows that the lower crust and lithospheric mantle of the Tarim basin underthrusts southwestward beneath the Altyn Tagh orogen, and intersects the northern Altyn Tagh fault at a small angle. This process results in the wedge-shaped low-velocity body found in the crust below the Altyn Tagh orogen (Figure 5). The Altyn Tagh fault, which separates the rigid Tarim basin from the soft Altyn Tagh orogen, accommodates the primary strike-slip and a minor thrust amount normal to the fault.

The change of material compositions of the middle and lower crust can be explained by the strike-slip fault between the Tarim and Altyn Tagh (Zhao et al., 2006). In the upper crust, the SW-NE directed convergence is accommodated by thrusting in the Altyn Tagh fault system, which generates the gentle slope across the system. In the lower crust, the convergence is transformed into plastic deformation or creep. Strike-slip deformation has been observed along the northern Altyn Tagh fault, with $120 \mathrm{~km}$ of left-lateral slip near Tula (Cowgill et al., 2000). The SW-directed thrusting of the lower crust and lithospheric mantle of the Tarim basin is normal to the Altyn Tagh fault with a distance of $160 \mathrm{~km}$, which is the same order of magnitude of left slip near Tula.

The shear wave splitting shows a polarization orientation $\mathrm{N} 60^{\circ} \mathrm{E}$ of fast wave beneath the Altyn Tagh orogen, indicating that crust and mantle creep is parallel to the northern Altyn Tagh fault. The high-resolution image indicates that the crust-mantle interface beneath the Altyn Tagh orogen and Qaidam basin is flat (Figure 5). Thus the tectonic deformation accommodated by creep of the lower crust can explain the uplift of the entire orogen (i.e. the crust-mantle boundary beneath the orogen is flat, Royden, 1996).

Our model agrees that the lower crust is soft, viscid, and can creep. It suggests that the lower crust of the Altyn Tagh orogen and Qaidam basin is of intermediate composition at depth and at a temperature of $500{ }^{\circ} \mathrm{C}$. Hence the lower crust of this region can behave plastically and experience channel flow (i.e. creep). The flow of lower crust is the primary mechanism for the origin of the eastern Tibetan plateau (Royden et al., 1997; Clark and Royden, 2000).

Previous studies on the Indian-Asian collision have reported the dislocation of the crust-mantle boundary below some major strike-slip faults, which suggests that these structures cut the entire lithosphere (Zhu and Helmberger, 1998; Vergne et al., 2002; Wittlinger et al., 2004). The previous seismic tomography shows that the Altyn Tagh fault is a lithospheric-scale tectonic boundary, which confines tectonic deformation to the inner part of the Altyn Tagh orogen and produces a large ramp in the Moho discontinuity. By contrast, our $\mathrm{P}$ wave velocity model indicates that the crust-mantle boundary between the Altyn Tagh orogen and Qaidam basin is flat and intact, implying that the Altyn Tagh fault is probably confined to the crust. As inferred by previous work, south of the study area (i.e. the Tibetan plateau south of the Qaidam basin), seismic profiles and results of receiver function analysis demonstrate that the crust contains a profound low-velocity layer in the middle crust which is not distinguished in our work, and the crustal thickness is larger than that of our work by 10-25 km (Nelson et al., 1996; Kind et al., 2002).

The recent GPS measurements suggest that the slip rate along the Altyn Tagh fault is about $9 \mathrm{~mm} / \mathrm{a}$ (Bendick et al., 2000; Shen et al., 2001), which is significantly lower than that from geological estimation 20-30 mm/a (Peltzer et al., 1989). This suggests that the $25 \mathrm{~mm} / \mathrm{a}$ displacement rate between the Tibetan plateau and the Tarim basin is much larger than the slip rate of the Altyn Tagh fault from geological evidence. This is likely the result of strike-slipping motion being accommodated by one or more faults in the middle and northern Tibetan plateau, such as the Kunlun fault, which is supported by the recent large magnitude ( $\left.M_{\mathrm{W}} 7.8\right) 2001$ Kunlun earthquake.

In the eastern margin of the Tarim basin, the litho- 
spheric mantle together with the lower crust underthrusts toward the southwest and intersects the strike of the Altyn Tagh fault and results in NE-SW compression at a small angle. Such a tectonic relation results in thrust faulting, and uplift of the wedge-shape crust-mantle mix. The Altyn Tagh orogen is characterized by crustal-scale strike-slip motion and NE-SW directed crustal shortening, which is accommodated by (1) crustal thickening caused by thrusting of the upper crust and flow (creep) of the lower crust; and (2) underthrusting of lithospheric mantle and lower crust of the eastern Tarim basin at a small angle with respect to the Altyn Tagh orogen.

\subsection{Qaidam basin}

Below the Altyn Tagh orogen and Qaidam basin, the Moho discontinuity is flat and there is no evidence that the Qaidam basin is being underthrusted beneath the Altyn Tagh orogen. This implies that active deformation of this region is accommodated by plastic deformation of the lower crust or lateral flow (creep). The Altyn Tagh orogen is separated from the Qaidam basin by strike-slip faulting. The rigidity of the Qaidam basin is less than that of the Tarim basin, thus its basement and interior have experienced intense deformation during tectonic evolution.

The crust of the eastern Tarim basin, is composed of a felsic upper, intermediate middle, and mafic (highvelocity) lower layers, which has features of a typical stable continental platform. By contrast, the crust of the northern Tibetan plateau lacks a mafic lower crust.
The velocity-depth structure below the Altyn Tagh orogen is very close to that of the Qaidam basin, meaning they belong to the same tectonic domain.

\section{Focal mechanism solutions of earthquakes}

\subsection{Principle}

Mechanisms of earthquakes can be classified into three types, normal faulting, reverse faulting, and strike-slip faulting, which represent three distinct stress states: extension, compression, and shear, respectively (Aki and Richards, 2002). They reveal the physical essential and regularity of crustal deformation and are vital for research of seismicity and earthquake origins. At present, classification of earthquake mechanisms are primarily based on geological investigations of surface ruptures and focal mechanism solutions of earthquakes. The latter makes use of modern seismic network (array) technology, and displays stress state and rupture sense of an earthquake on the Wolff net intuitively.

Shortly after that, Apperson and Frohlich (1988) proposed the triangle diagram method (Figure 6) to display earthquake types intuitively and quantitatively. In this method, the parameters of a focal mechanism solution ( $P$-axis, $T$-axis and $B$-axis) are transformed into proportional relations in the normal, reverse and strike-slip faulting types. Then it uses projection of the azimuthal sphere to determine the types

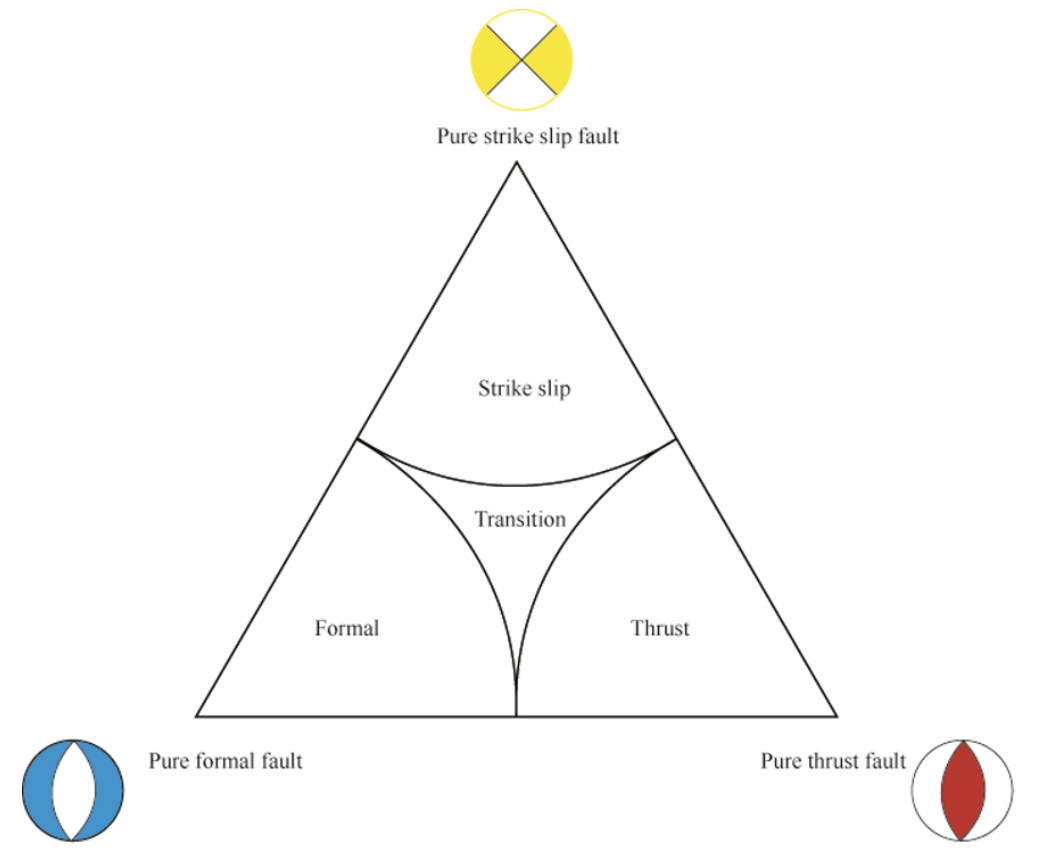

Figure 6 Triangle diagram showing earthquake types. 
of the earthquake according to its position on the diagram: normal faulting, reverse faulting, strike-slip faulting, and residual type (Frohlich, 1992). By the projection on different areas of the triangle, the types of earthquake focal mechanism can be identified, which correspond to seismogenic stress states of extension, compression, shear and transition, which reflect stress and strain states in the crust and the corresponding deformation process.

The orientation of a seismic rupture is a three dimensional problem that depends on three independent physical parameters. Thus, the dip angles of the $P$-, $T$ - and $B$-axes can be used to determine the type of earthquake. Suppose an earthquake has dip parameters $\left(\delta_{P}, \delta_{T}, \delta_{B}\right)$, with values $\left(90^{\circ}, 0^{\circ}, 0^{\circ}\right),\left(0^{\circ}, 90^{\circ}, 0^{\circ}\right)$, and $\left(0^{\circ}, 0^{\circ}, 90^{\circ}\right)$, which represent pure normal, pure reverse, and pure strike-slip faulting, respectively. Their projections on the triangle diagram of Frohlich et al. constitute three apexes of the triangle. Each of the values $\left(\delta_{P}, \delta_{T}, \delta_{B}\right)$ can range between $0^{\circ}$ and $90^{\circ}$, and they are constrained by each other. Through transformation of the azimuth sphere center, these values are projected on the triangle to exhibit the type of earthquake. In a reverse way, based on the coordinates of a point and the type on the triangle, the corresponding values of $\left(\delta_{P}, \delta_{T}, \delta_{B}\right)$ can be determined.

According to the transformation of azimuth sphere center (Apperson and Frohlich, 1988), coordinates $(x, y)$ of a point in the triangle are

$$
x=\frac{\cos \delta_{B} \sin \psi}{\sin 35.26^{\circ} \cos \delta_{B}+\cos 35.26^{\circ} \sin \delta_{B} \cos \psi}
$$

and

$$
y=\frac{\cos 35.26^{\circ} \sin \delta_{B}-\sin 35.26^{\circ} \cos \delta_{B} \cos \psi}{\sin 35.26^{\circ} \cos \delta_{B}+\cos 35.26^{\circ} \sin \delta_{B} \cos \psi},
$$

where

$$
\psi=\arctan \left(\frac{\sin \delta_{T}}{\sin \delta_{P}}\right)-45^{\circ} .
$$

When the seismogenic stress axes $\left(\delta_{P}, \delta_{T}, \delta_{B}\right)=\left(35.26^{\circ}\right.$, $\left.35.26^{\circ}, 35.26^{\circ}\right)$, this point lies at the center of the triangle $x=0, y=0$.

Based on sphere geometry, dip angles $\left(\delta_{P}, \delta_{T}, \delta_{B}\right)$ of the stress axes satisfy the following formula:

$$
\sin ^{2} \delta_{P}+\sin ^{2} \delta_{T}+\sin ^{2} \delta_{B}=1 .
$$

From this formula, Apperson and Frohlich (1988) considered that the proportional relation in three types of focal mechanisms is correlated with $\sin 2 \delta_{P}, \sin 2 \delta_{T}$ and $\sin 2 \delta_{B}$. Therefore, in terms of the proportional relations of $\delta_{T}=40^{\circ}, \delta_{P}$ or $\delta_{B}=30^{\circ}$, earthquake focal mechanisms are classified into reverse faulting, normal faulting, strike-slip faulting, and residual types (Frohlich, 1992), which represent three distinct or transitional stress states within the crust.

On the Harvard University seismic moment tensor database website, focal mechanism solutions of all M4.5 or greater earthquakes around the world can be accessed. By projecting these data onto the areas of distinct seismic types, the type of focal mechanisms can be determined, and then used for crustal deformation research.

\subsection{Focal mechanism solutions of earthquakes}

In the range of $80^{\circ} \mathrm{E}-96^{\circ} \mathrm{E}, 36^{\circ} \mathrm{N}-44^{\circ} \mathrm{N}$, from Baicheng, Xinjiang to Da Qaidam, Qinghai, there have been $28 M \geq 4.5$ earthquakes since 1976 (see Table 2), mostly exceeding $M 5$ and having a maximum of $M 6.1$.

Their focal mechanism solutions show consistent maximum principal stresses that are oriented subhorizontally in a N-S direction, with least and intermediate principal stresses having various orientations, indicative of partitioned features of earthquake types. The fault nodal planes are largely oriented in near EW, NW, or SW directions. Most events are of reverse fault type, except strike-slip shocks, which occurred in the Tianshan and the Altyn Tagh orogens.

\subsection{Geological interpretation}

The Baicheng-Da Qaidam transect crosses the southern Tianshan, the Tarim basin and the Altyn Tagh orogen. This region is mostly dominated by NS-directed compression and vertical uplift, with strike-slip motions being confined to the faults in the southern Tianshan and Altyn Tagh orogen. Such a character of the tectonic deformation is associated with crustal thickening of this region.

\section{Terrestrial heat flow}

Along the transect and its surrounding areas, a total of 53 terrestrial heat flow values have been collected (Table 3).

The heat flow data presented in Table 3 include 20 values along the northern edge of the Tarim basin (western section of the transect), 3 values at the Kongqi river slope (east end of the Tarim, in the middle transect), and 30 values along the eastern extent of the transect. These data show that the heat flow is relatively high along the eastern section and low along the west section 
Table 2 Catalogue of focal mechanism solutions of earthquakes

\begin{tabular}{|c|c|c|c|c|c|c|c|c|c|c|c|c|c|c|c|c|c|}
\hline \multicolumn{2}{|c|}{ Origin time } & \multicolumn{2}{|c|}{ Location } & \multirow{2}{*}{$\begin{array}{c}\text { Depth } \\
\text { / km }\end{array}$} & \multirow{2}{*}{$M_{-}$} & \multicolumn{3}{|c|}{ Nodal plane 1} & \multicolumn{3}{|c|}{ Nodal plane 2} & \multicolumn{3}{|c|}{$P$ axis } & \multicolumn{3}{|c|}{$T$ axis } \\
\hline $\begin{array}{c}\text { Date } \\
\text { a-mo-d }\end{array}$ & $\begin{array}{c}\text { Time } \\
\text { h:min:s }\end{array}$ & at. $/{ }^{\circ} \mathrm{N}$ & Long. $/{ }^{\circ} \mathrm{E}$ & & & $\begin{array}{c}\text { Strike } \\
1{ }^{\circ}\end{array}$ & $\begin{array}{r}\text { Dip } \\
/{ }^{\circ}\end{array}$ & $\begin{array}{c}\text { Rake } \\
{ }^{\circ}\end{array}$ & $\begin{array}{c}\text { Strike } \\
{ }^{\circ}\end{array}$ & $\begin{array}{r}\text { Dip } \\
/{ }^{\circ}\end{array}$ & $\begin{array}{c}\text { Rake } \\
{ }^{\circ}\end{array}$ & $\begin{array}{c}\text { Strike } \\
{ }^{\circ}\end{array}$ & $\begin{array}{r}\text { Dip } \\
{ }^{\circ}\end{array}$ & $\begin{array}{c}\text { Rake } \\
1{ }^{\circ}\end{array}$ & $\begin{array}{c}\text { Strike } \\
{ }^{\circ}\end{array}$ & $\begin{array}{r}\text { Dip } \\
/{ }^{\circ}\end{array}$ & $\begin{array}{c}\text { Rake } \\
{ }^{\circ}\end{array}$ \\
\hline 1977-01-01 & 6.00 & 2820 & 9067 & 100 & 6.0 & 3 & 37 & 127 & 98 & 61 & 65 & 65 & 325 & 21 & 111 & 13 & 206 \\
\hline 1977-01-19 & $00: 46: 22.40$ & 3 & & & 0.0 & & 35 & 00 & 135 & 58 & 105 & 73 & 82 & 12 & 07 & 12 & 215 \\
\hline $1977-07-23$ & 06:57:08.90 & 42.20 & 83.59 & 33.0 & 5.4 & 299 & 19 & 118 & 90 & 74 & 81 & 60 & 347 & 9 & 93 & 28 & 187 \\
\hline 1978-04-22 & 15:04:25.10 & 42.26 & 86.54 & 15.0 & 5.3 & 336 & 38 & 135 & 104 & 64 & 61 & 60 & 331 & 26 & 117 & 14 & 214 \\
\hline 1979-03-29 & 02:01:35.40 & 41.93 & 83.69 & 15.0 & 5.6 & 279 & 29 & 107 & 80 & 63 & 81 & 71 & 330 & 8 & 84 & 17 & 177 \\
\hline 1979-09-28 & 46.508 & 2781 & 004 & 50 & 5.1 & 12 & 23 & 42 & 359 & 75 & 107 & 57 & 291 & 17 & 174 & 28 & 75 \\
\hline 1979-12-02 & 01:37:15.80 & 50.00 & 90.09 & 12.0 & 5.5 & 200 & 67 & 20 & 157 & 72 & 155 & 30 & 115 & 60 & 303 & 4 & 207 \\
\hline 1980-06-01 & 06:19:02.00 & 38.98 & 0.90 & 15.0 & 5.4 & 334 & 34 & 93 & 1 & 56 & 88 & 79 & 54 & 2 & 152 & 11 & 242 \\
\hline 1980-07-12 & 20:39:41.70 & 37.03 & 94.08 & 15.0 & 5.2 & 161 & 9 & 106 & 324 & 82 & 88 & 53 & 231 & 2 & 325 & 37 & 57 \\
\hline $1985-08-11$ & $16: 06: 04.90$ & 36.41 & 958 & 10.0 & 5.3 & 200 & 33 & 123 & 342 & 63 & 70 & 66 & 216 & 17 & 352 & 16 & 87 \\
\hline 1987-01-05 & 2 & & & 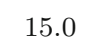 & 0.1 & 226 & 21 & 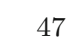 & 0 & 75 & 104 & 58 & 19 & -2 & 201 & 29 & 167 \\
\hline 1987-02-25 & .00 .40 .2 & .00 & 91.08 & 10. & 5.8 & 127 & 36 & 124 & 267 & 60 & 68 & 67 & 135 & 19 & 278 & 13 & 13 \\
\hline 1990-01-14 & 03:03:30.90 & 37.60 & 2.10 & 15.0 & 6.0 & 2 & 45 & 41 & 310 & 63 & 127 & 56 & 269 & 32 & 111 & 10 & 15 \\
\hline 1990-10-24 & 23:38:15.20 & 43.79 & 83.99 & 15.0 & 5.2 & 106 & 48 & 141 & 224 & 62 & 49 & 54 & 83 & 35 & 247 & 8 & 342 \\
\hline 1993-10-02 & 08:42:38.80 & 38.16 & 88.82 & 15.0 & 6.1 & 326 & 42 & 146 & 82 & 68 & 53 & 52 & 309 & 34 & 98 & 15 & 198 \\
\hline 1994-09-07 & $13: 56: 24.30$ & 42 & 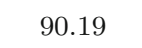 & 33.0 & 5.2 & 238 & 58 & -6 & 331 & 85 & -148 & 18 & 100 & 58 & 338 & 25 & 199 \\
\hline $5-02$ & 1 & 4 & 84.54 & 18.0 & 5 . & 98 & 57 & 170 & 4 & 81 & 24 & 30 & 61 & 5 & 207 & 16 & 322 \\
\hline 1995-09-26 & 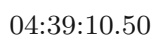 & 42.02 & & 43.0 & 0. & b & 38 & 77 & 2 & 54 & 100 & 19 & 30 & 8 & 256 & 8 & 165 \\
\hline 1995-11-01 & $12: 29: 29.70$ & 42.99 & 80.31 & 15.0 & 5.2 & 270 & 13 & 100 & 80 & 77 & 88 & 58 & 347 & 2 & 80 & 32 & 172 \\
\hline $1998-06-25$ & 06:39:19.90 & 41.16 & 80.44 & 15.1 & 5.1 & 262 & 27 & 129 & 39 & 69 & 72 & 61 & 282 & 17 & 45 & 22 & 143 \\
\hline 1998-07-28 & 04:51:47.00 & 4193 & 0150 & 46.9 & 5.1 & 260 & 42 & 88 & 83 & 48 & 92 & 87 & 17 & 1 & 261 & 3 & 171 \\
\hline 1999-03-15 & 101 & $410 e$ & (2) & 170 & 5.4 & 270 & 19 & 1 & 52 & 77 & 76 & 56 & 304 & 13 & 55 & 30 & 153 \\
\hline 2000-01-31 & :26:01.7 & (2) & 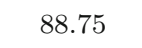 & 33.0 & 5.4 & 347 & 76 & 167 & 0 & 77 & 1 & 19 & 304 & 71 & 121 & 1 & 214 \\
\hline 2003-12-01 & 01:38:37.06 & 42 & 50 & 15.0 & 6.0 & 281 & 14 & 122 & 69 & 78 & 83 & 56 & 329 & 7 & 70 & 33 & 165 \\
\hline 2005-09-23 & 05:00:58.41 & 41.97 & 82.46 & 12.0 & 4.8 & 105 & 37 & 111 & 260 & 56 & 75 & 74 & 129 & 12 & 268 & 10 & 1 \\
\hline 2006-04-28 & 18:01:28.48 & 41.74 & - & 20.8 & 4.9 & 251 & 37 & 90 & 2 & 53 & 50 & 82 & 343 & 0 & 252 & 8 & 162 \\
\hline 2007-02-02 & $22: 32: 23.94$ & 37.87 & 0185 & 20.2 & 5.4 & 111 & 45 & 114 & 258 & 49 & 37 & 73 & 101 & 17 & 273 & 2 & 4 \\
\hline 2007-07-20 & 10:06:55.72 & 42.93 & 82.38 & 25.3 & 5.6 & 324 & 66 & 175 & 55 & 86 & 24 & 20 & 282 & 65 & 65 & 14 & 187 \\
\hline
\end{tabular}

Table 3 Terrestrial heat flow values in the transect corridor domain of Baicheng-Da Qaidam

\begin{tabular}{|c|c|c|c|c|c|c|c|}
\hline \multirow{2}{*}{ No. } & \multirow{2}{*}{ Code } & \multicolumn{2}{|c|}{ Location } & \multirow{2}{*}{$\begin{array}{c}\text { Heat flow } \\
/\left(\mathrm{mW} \cdot \mathrm{m}^{-2}\right)\end{array}$} & \multirow{2}{*}{$\begin{array}{c}\text { Quality } \\
\text { rank }\end{array}$} & \multirow{2}{*}{ Data source } & \multirow{2}{*}{ Tectonic site } \\
\hline & & E. Long. & N. lat. & & & & \\
\hline 1 & HF00759 & $95^{\circ} 48^{\prime} 41^{\prime \prime}$ & $37^{\circ} 30^{\prime} 56^{\prime \prime}$ & 40.8 & $\mathrm{~B}$ & Hu et al. (2001) & Qaidam basin \\
\hline 2 & HF00752 & $95^{\circ} 34^{\prime} 59^{\prime \prime}$ & $37^{\circ} 19^{\prime} 36^{\prime \prime}$ & 53.7 & $\mathrm{C}$ & Hu et al. (2001) & Qaidam basin \\
\hline 3 & HF00051 & $95^{\circ} 34^{\prime} 00^{\prime \prime}$ & $37^{\circ} 19^{\prime} 00^{\prime \prime}$ & 63.0 & $\mathrm{~A}$ & Shen et al. (1995) & Qaidam basin \\
\hline 4 & HF00064 & $95^{\circ} 33^{\prime} 07^{\prime \prime}$ & $37^{\circ} 18^{\prime} 09^{\prime \prime}$ & 40.0 & B & Shen et al. (1992) & Qaidam basin \\
\hline 5 & HF01180 & $95^{\circ} 07^{\prime} 00^{\prime \prime}$ & $38^{\circ} 06^{\prime} 00^{\prime \prime}$ & 54.9 & $\mathrm{~A}$ & Liang et al. (1992) & Qaidam basin \\
\hline 6 & HF01181 & $94^{\circ} 54^{\prime} 18^{\prime \prime}$ & $38^{\circ} 02^{\prime} 30^{\prime \prime}$ & 67.4 & A & Liang et al. (1992) & Qaidam basin \\
\hline 7 & HF00865 & $94^{\circ} 50^{\prime} 00^{\prime \prime}$ & $38^{\circ} 00^{\prime} 00^{\prime \prime}$ & 60.0 & A & Hu et al. (2001) & Qaidam basin \\
\hline 8 & HF00749 & $94^{\circ} 33^{\prime} 25^{\prime \prime}$ & $38^{\circ} 47^{\prime} 58^{\prime \prime}$ & 47.7 & A & Hu et al. (2001) & Qaidam basin \\
\hline 9 & HF00751 & $94^{\circ} 11^{\prime} 18^{\prime \prime}$ & $37^{\circ} 55^{\prime} 34^{\prime \prime}$ & 34.5 & A & Hu et al. (2001) & Qaidam basin \\
\hline
\end{tabular}


Continued on from Table 3

\begin{tabular}{|c|c|c|c|c|c|c|c|}
\hline \multirow{2}{*}{ No. } & \multirow{2}{*}{ Code } & \multicolumn{2}{|c|}{ Location } & \multirow{2}{*}{$\begin{array}{l}\text { Heat flow } \\
/\left(\mathrm{mW} \cdot \mathrm{m}^{-2}\right)\end{array}$} & \multirow{2}{*}{$\begin{array}{l}\text { Quality } \\
\text { rank }\end{array}$} & \multirow{2}{*}{ Data source } & \multirow{2}{*}{ Tectonic site } \\
\hline & & E. Long. & N. lat. & & & & \\
\hline 10 & HF00864 & $94^{\circ} 11^{\prime} 00^{\prime \prime}$ & $37^{\circ} 53^{\prime} 00^{\prime \prime}$ & 57.0 & $\mathrm{~B}$ & Shen et al. (1994) & Qaidam basin \\
\hline 11 & HF01085 & $94^{\circ} 09^{\prime} 00^{\prime \prime}$ & $37^{\circ} 23^{\prime} 00^{\prime \prime}$ & 35.0 & B & Shen et al. (1994) & Qaidam basin \\
\hline 12 & HF00863 & $93^{\circ} 47^{\prime} 00^{\prime \prime}$ & $38^{\circ} 26^{\prime} 00^{\prime \prime}$ & 54.0 & A & Shen et al. (1994) & Qaidam basin \\
\hline 13 & HF01090 & $93^{\circ} 35^{\prime} 00^{\prime \prime}$ & $38^{\circ} 21^{\prime} 00^{\prime \prime}$ & 42.0 & B & Shen et al. (1994) & Qaidam basin \\
\hline 14 & HF00750 & $93^{\circ} 21^{\prime} 09^{\prime \prime}$ & $38^{\circ} 26^{\prime} 50^{\prime \prime}$ & 36.7 & B & Hu et al. (2001) & Qaidam basin \\
\hline 15 & HF00861 & $93^{\circ} 19^{\prime} 00^{\prime \prime}$ & $38^{\circ} 39^{\prime} 00^{\prime \prime}$ & 49.0 & B & Hu et al. (2001) & Qaidam basin \\
\hline 16 & HF00862 & $93^{\circ} 18^{\prime} 00^{\prime \prime}$ & $38^{\circ} 32^{\prime} 00^{\prime \prime}$ & 48.0 & A & Shen et al. (1994) & Qaidam basin \\
\hline 17 & HF00859 & $92^{\circ} 45^{\prime} 00^{\prime \prime}$ & $37^{\circ} 53^{\prime} 00^{\prime \prime}$ & 63.0 & $\mathrm{~A}$ & Shen et al. (1994) & Qaidam basin \\
\hline 18 & HF00857 & $92^{\circ} 24^{\prime} 00^{\prime \prime}$ & $38^{\circ} 35^{\prime} 00^{\prime \prime}$ & 66.0 & B & Shen et al. (1994) & Qaidam basin \\
\hline 19 & HF00860 & $92^{\circ} 20^{\prime} 00^{\prime \prime}$ & $37^{\circ} 18^{\prime} 00^{\prime \prime}$ & 61.0 & A & Shen et al. (1994) & Qaidam basin \\
\hline 20 & HF00858 & $92^{\circ} 04^{\prime} 00^{\prime \prime}$ & $38^{\circ} 08^{\prime} 00^{\prime \prime}$ & 51.0 & A & Shen et al. (1994) & Qaidam basin \\
\hline 21 & HF00855 & $91^{\circ} 46^{\prime} 00^{\prime \prime}$ & $38^{\circ} 33^{\prime} 00^{\prime \prime}$ & 65.0 & B & Shen et al. (1994) & Qaidam basin \\
\hline 22 & HF00856 & $91^{\circ} 40^{\prime} 00^{\prime \prime}$ & $37^{\circ} 45^{\prime} 00^{\prime \prime}$ & 66.0 & $\mathrm{D}$ & Shen et al. (1994) & Qaidam basin \\
\hline 23 & HF01086 & $91^{\circ} 38^{\prime} 00^{\prime \prime}$ & $37^{\circ} 54^{\prime} 00^{\prime \prime}$ & 32.0 & B & Shen et al. (1994) & Qaidam basin \\
\hline 24 & HF00851 & $91^{\circ} 23^{\prime} 00^{\prime \prime}$ & $38^{\circ} 10^{\prime} 00^{\prime \prime}$ & 66.0 & A & Shen et al. (1994) & Qaidam basin \\
\hline 25 & HF00854 & $91^{\circ} 20^{\prime} 00^{\prime \prime}$ & $37^{\circ} 51^{\prime} 00^{\prime \prime}$ & 65.0 & A & Shen et al. (1994) & Qaidam basin \\
\hline 26 & HF01087 & $91^{\circ} 08^{\prime} 00^{\prime \prime}$ & $38^{\circ} 22^{\prime} 00^{\prime \prime}$ & 36.0 & B & Shen et al. (1994) & Qaidam basin \\
\hline 26 & HF00852 & $91^{\circ} 06^{\prime} 00^{\prime \prime}$ & $37^{\circ} 56^{\prime} 00^{\prime \prime}$ & 53.0 & B & Shen et al. (1994) & Qaidam basin \\
\hline 28 & HF00853 & $90^{\circ} 57^{\prime} 00^{\prime \prime}$ & $38^{\circ} 02^{\prime} 00^{\prime \prime}$ & 75.0 & B & Shen et al. (1994) & Qaidam basin \\
\hline 29 & HF00850 & $90^{\circ} 47^{\prime} 00^{\prime \prime}$ & $38^{\circ} 14^{\prime} 00^{\prime \prime}$ & 43.0 & $\mathrm{D}$ & Shen et al. (1994) & Qaidam basin \\
\hline 30 & HF00849 & $90^{\circ} 39^{\prime} 00^{\prime \prime}$ & $38^{\circ} 18^{\prime} 00^{\prime \prime}$ & 59.0 & A & Shen et al. (1994) & Qaidam basin \\
\hline 31 & HF01046 & $88^{\circ} 06^{\prime} 36^{\prime \prime}$ & $40^{\circ} 16^{\prime} 36^{\prime \prime}$ & 56.1 & A & Wang et al. (1994) & Tarim east end \\
\hline 32 & HF00449 & $87^{\circ} 56^{\prime} 22^{\prime \prime}$ & $40^{\circ} 31^{\prime} 59^{\prime \prime}$ & 56.1 & $\mathrm{C}$ & Wang (2000) & Tarim east end \\
\hline 33 & HF00506 & $87^{\circ} 40^{\prime} 00^{\prime \prime}$ & $40^{\circ} 45^{\prime} 00^{\prime \prime}$ & 52.5 & B & Wang (2000) & Tarim east end \\
\hline 34 & HF00507 & $85^{\circ} 56^{\prime} 00^{\prime \prime}$ & $41^{\circ} 45^{\prime} 00^{\prime \prime}$ & 43.2 & B & Wang (2000) & Tarim north edge \\
\hline 35 & HF00458 & $85^{\circ} 16^{\prime} 59^{\prime \prime}$ & $41^{\circ} 22^{\prime} 51^{\prime \prime}$ & 45.9 & $\mathrm{C}$ & Wang (2000) & Tarim north edge \\
\hline 36 & HF00945 & $84^{\circ} 44^{\prime} 00^{\prime \prime}$ & $41^{\circ} 43^{\prime} 00^{\prime \prime}$ & 43.9 & $\mathrm{C}$ & Hu et al. (2001) & Tarim north edge \\
\hline 37 & HF01033 & $84^{\circ} 43^{\prime} 19^{\prime \prime}$ & $41^{\circ} 47^{\prime} 31^{\prime \prime}$ & 42.6 & A & Wang et al. (1994) & Tarim north edge \\
\hline 38 & HF01047 & $84^{\circ} 29^{\prime} 16^{\prime \prime}$ & $41^{\circ} 29^{\prime} 00^{\prime \prime}$ & 43.9 & B & Wang et al. (1994) & Tarim north edge \\
\hline 39 & HF01048 & $84^{\circ} 26^{\prime} 20^{\prime \prime}$ & $41^{\circ} 25^{\prime} 10^{\prime \prime}$ & 40.9 & B & Wang et al. (1994) & Tarim north edge \\
\hline 40 & HF01031 & $84^{\circ} 23^{\prime} 00^{\prime \prime}$ & $41^{\circ} 29^{\prime} 25^{\prime \prime}$ & 41.4 & A & Wang et al. (1994) & Tarim north edge \\
\hline 41 & HF00946 & $84^{\circ} 23^{\prime} 00^{\prime \prime}$ & $41^{\circ} 50^{\prime} 00^{\prime \prime}$ & 44.1 & $\mathrm{C}$ & Hu et al. (2001) & Tarim north edge \\
\hline 42 & HF00436 & $84^{\circ} 15^{\prime} 04^{\prime \prime}$ & $41^{\circ} 45^{\prime} 55^{\prime \prime}$ & 49.0 & A & Wang (2000) & Tarim north edge \\
\hline 43 & HF00435 & $84^{\circ} 14^{\prime} 45^{\prime \prime}$ & $41^{\circ} 19^{\prime} 00^{\prime \prime}$ & 49.0 & A & Wang (2000) & Tarim north edge \\
\hline 44 & HF01030 & $84^{\circ} 08^{\prime} 47^{\prime \prime}$ & $41^{\circ} 33^{\prime} 36^{\prime \prime}$ & 48.0 & A & Wang et al. (1994) & Tarim north edge \\
\hline 45 & HF00434 & $84^{\circ} 04^{\prime} 20^{\prime \prime}$ & $41^{\circ} 26^{\prime} 08^{\prime \prime}$ & 47.8 & A & Wang (2000) & Tarim north edge \\
\hline 46 & HF01045 & $83^{\circ} 39^{\prime} 31^{\prime \prime}$ & $42^{\circ} 18^{\prime} 24^{\prime \prime}$ & 56.1 & B & Wang et al. (1994) & Tarim north edge \\
\hline 47 & HF00505 & $83^{\circ} 12^{\prime} 00^{\prime \prime}$ & $41^{\circ} 38^{\prime} 00^{\prime \prime}$ & 43.0 & B & Wang (2000) & Tarim north edge \\
\hline 48 & HF01049 & $83^{\circ} 10^{\prime} 50^{\prime \prime}$ & $40^{\circ} 58^{\prime} 33^{\prime \prime}$ & 42.2 & B & Wang et al. (1994) & Tarim north edge \\
\hline 49 & HF01032 & $83^{\circ} 07^{\prime} 37^{\prime \prime}$ & $41^{\circ} 47^{\prime} 33^{\prime \prime}$ & 41.0 & B & Wang et al. (1994) & Tarim north edge \\
\hline 50 & HF00503 & $83^{\circ} 01^{\prime} 00^{\prime \prime}$ & $42^{\circ} 00^{\prime} 00^{\prime \prime}$ & 35.3 & B & Wang (2000) & Tarim north edge \\
\hline 51 & HF01034 & $82^{\circ} 15^{\prime} 13^{\prime \prime}$ & $42^{\circ} 01^{\prime} 22^{\prime \prime}$ & 55.6 & B & Wang et al. (1994) & Tarim north edge \\
\hline 52 & HF00501 & $82^{\circ} 10^{\prime} 00^{\prime \prime}$ & $42^{\circ} 00^{\prime} 00^{\prime \prime}$ & 44.9 & B & Wang (2000) & Tarim north edge \\
\hline 53 & HF00497 & $82^{\circ} 02^{\prime} 00^{\prime \prime}$ & $42^{\circ} 04^{\prime} 00^{\prime \prime}$ & 47.8 & B & Wang (2000) & Tarim north edge \\
\hline
\end{tabular}


of the transect. It varies from 35 to $56 \mathrm{~mW} \cdot \mathrm{m}^{-2}$ in the northern edge of the Tarim with an average of $45.3 \mathrm{~mW} \cdot \mathrm{m}^{-2}$, and $54.9 \mathrm{~mW} \cdot \mathrm{m}^{-2}$ at the Kongqi river slope (east end of Tarim). Within the Qaidam basin, heat flow values exhibit a large variation ranging from 32 to $75 \mathrm{~mW} \cdot \mathrm{m}^{-2}$. Because such a variation occurs over a small distance, it is interpreted to originate from the shallow subsurface rather than deep within the basin (Jaupart, 1983). It is noted that in the NE direction, normal to the strike of the shallow tectonics of the Qaidam basin, the values of heat flow fluctuate regularly. Thus it is inferred that the "refracation effect" of heat conduction caused by varing thermal conductivity in the shallow crust, which is associated with the NW-trending fold-thrust structure in the basin, is the primary factor that produces the changing heat flow. Therefore, in this work the heat flow data are divided into seven sets in a NW direction and the average is calculated for each. The average heat flow of these seven sets is calculated to yield $52.5 \mathrm{~mW} \cdot \mathrm{m}^{-2}$ as the regional average of the Qaidam basin.

Along the northern edge of the Tarim basin, where the western section of the transect passes, low heat flow values (Table 3) suggest a "cold" lithosphere. While in the eastern section of the transect, the Qaidam basin is of intermediate heat flow, or moderate lithosphere in thermal regime. As a whole, the average heat flow is lower than in eastern China by $10-20 \mathrm{~mW} \cdot \mathrm{m}^{-2}$ (Wang, 2001), which is likely the result of low heat generation rates within the crust and low heat flow from the mantle, or a relatively thicker lithospheric mantle in this area.

Based on global mantle heat flow estimations of continents, the lower limit of mantle heat flow is 10$18 \mathrm{~mW} \cdot \mathrm{m}^{-2}$ (McLennan et al., 2005). According to Wang (2006), subtracting the lower limit of mantle heat flow $10 \mathrm{~mW} \cdot \mathrm{m}^{-2}$ from the avegage heat flow (or representative heat flow) of tectonic domain of the transect domain, yields the heat flow of the upper crust. To obtain the upper average heat generation rate of the crust, this value is then divided by the average crustal thickness (Table 4). The results indicates that the average heat generation rate of the crust in this area is $0.64-0.67 \mu \mathrm{W} \cdot \mathrm{m}^{-3}$, which is very close to that value 0.6-0.8 $\mu \mathrm{W} \cdot \mathrm{m}^{-3}$ (Wang, 2006), but slightly lower than the global average 0.7 of continents (McLennan et al., 2005). This indicates that the crust of the transect domain has a lower heat generation rate, which agrees to previous studies (Wang, 2006, 2007), and with the geological inference that the basements of the Tarim basin and the Qaidam basin are residual oceanic basins (Hsu and Chen, 1999).

Using the estimated heat generation rate of the crust and geochemical data (Wang, 2007) and the crustal structures of each tectonic domain, taking $0.6 \mu \mathrm{W} \cdot \mathrm{m}^{-3}$ for Tarim and Qaidam, the thermal structure of each tectonic domain is calculated. Based on the assumption of 1-D steady heat conduction, using thermal conductivity varying with temperature and pressure (Wang, 2001), the geothermal lines of tectonic domains are determined. Here, the surface temperature is set as $0{ }^{\circ} \mathrm{C}$ and the heat generation of mantle is ignored. The thicknesses of each crust layer and their heat generation rates are listed in Table 5 .

Table 4 Upper limit of heat generation rate of crust in Baicheng-Da Qaidam domain

\begin{tabular}{cccc}
\hline Tectonic unit & $\begin{array}{c}\text { Heat flow } \\
\left(\mathrm{mW} \cdot \mathrm{m}^{-2}\right)\end{array}$ & $\begin{array}{c}\text { Crustal } \\
\text { thickness } / \mathrm{km}\end{array}$ & $\begin{array}{c}\text { Heat generation } \\
\text { rate } /\left(\mu \mathrm{W} \cdot \mathrm{m}^{-3}\right)\end{array}$ \\
\hline $\begin{array}{l}\text { Tarim basin } \\
\text { north edge }\end{array}$ & 45.3 & 55 & 0.64 \\
Qaidam basin & 52.5 & 63 & 0.67 \\
\hline
\end{tabular}

Table 5 Crustal layer thickness $(h)$ and heat generation rate $(K)$ in the Baicheng-Da Qaidam domain

\begin{tabular}{|c|c|c|c|c|c|c|c|c|c|}
\hline \multirow{2}{*}{ Basin } & \multicolumn{2}{|c|}{ Sedimentary cover } & \multicolumn{2}{|c|}{ Upper crust } & \multicolumn{2}{|c|}{ Middle crust } & \multicolumn{2}{|c|}{ Lower crust } & \multirow{2}{*}{$\begin{array}{c}\text { Mantle hear } \\
\text { flow } /\left(\mathrm{mW} \cdot \mathrm{m}^{-2}\right)\end{array}$} \\
\hline & $h / \mathrm{km}$ & $K /\left(\mu \mathrm{W} \cdot \mathrm{m}^{-3}\right)$ & $h / \mathrm{km}$ & $K /\left(\mu \mathrm{W} \cdot \mathrm{m}^{-3}\right)$ & $h / \mathrm{km}$ & $K /\left(\mu \mathrm{W} \cdot \mathrm{m}^{-3}\right)$ & $h / \mathrm{km}$ & $K /\left(\mu \mathrm{W} \cdot \mathrm{m}^{-3}\right)$ & \\
\hline Tarim basin north edge & 5 & 1.2 & 22 & 1.0 & 13 & 0.2 & 15 & 0.1 & 13.2 \\
\hline Tarim basin east end & 5 & 1.2 & 22 & 1.0 & 13 & 0.2 & 15 & 0.1 & 22.8 \\
\hline Qaidam basin & 4 & 1.2 & 24 & 1.2 & 11 & 0.2 & 24 & 0.1 & 14.3 \\
\hline
\end{tabular}

Calculation of the lithospheric geotemperature shows that the Moho temperature is $500{ }^{\circ} \mathrm{C}$ along the north edge of the Tarim basin, $800{ }^{\circ} \mathrm{C}$ at the east end of the Tarim basin, and $650{ }^{\circ} \mathrm{C}$ in the Qaidam basin (Figure 7 , Table 6 ). For all tectonic domains the lithospheric thickness is relatively great (Figure 7 ), being $\sim 225 \mathrm{~km}$ along the north edge of the Tarim basin, $120 \mathrm{~km}$ at the east end of the Tarim basin, and $190 \mathrm{~km}$ in the Qaidam basin. Because measured heat flow data in the eastern Tarim basin east are relatively few, it is assumed that 
heat generation rate there is the same as that of the northern edge of the Tarim, consequently the resultant geotemperature curves for the eastern Tarim represent only a rough estimation.

The 1-D calculation of thermal thickness indicates that the lithosphere along the northern of the Tarim is thicker than that of the Qaidam basin by $30-40 \mathrm{~km}$. Geophysical evidence suggests that the Tarim lithosphere underthrusts to the Tianshan orogen (Zhao,
2005). The thicker lithosphere along the northern edge of the Tarim is associated with the subduction of the cold Tarim domain beneath the Tianshan.

Below a depth of $60 \mathrm{~km}$ in the Qaidam basin, the temperature is higher than that in the northern Tarim basin by $100{ }^{\circ} \mathrm{C}$. And the higher geotemperature curves (Figure 7) are indicative of a thinner lithosphere in the eastern Tarim basin.
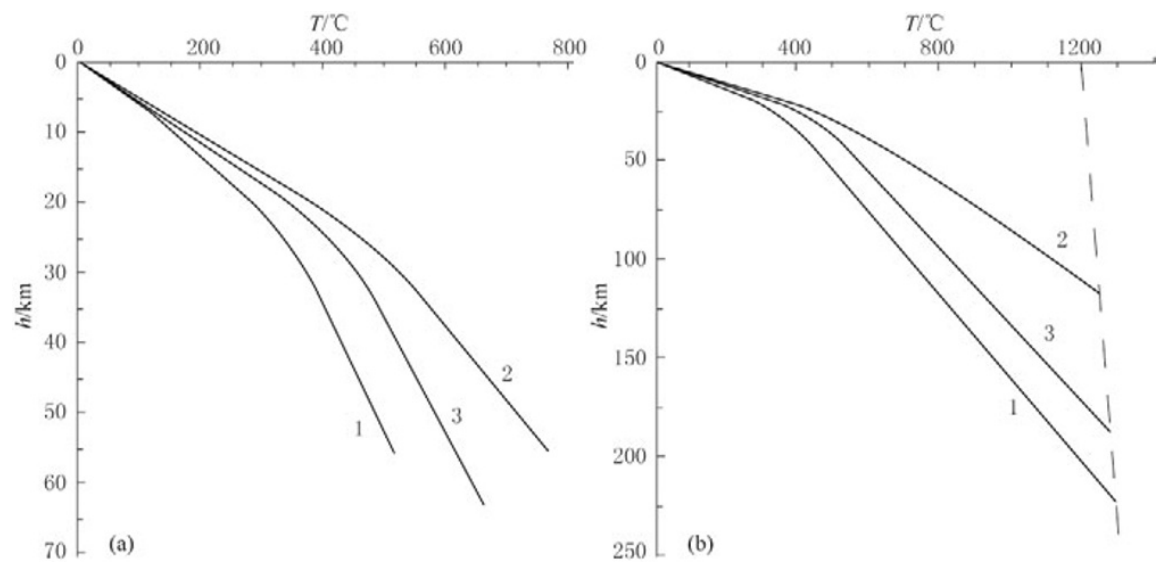

Figure 7 Geotemperature curves of the crust (a) and lithosphere (b) along the Baicheng-Da Qaidam transect domain. The dashed line on right of (b) is the geothermal adiabat of the mantle. Intersection between the geotemperature and the adiabat defines the depth of the base of the lithospheric. $h$ denote depth, $T$ is temperature; 1 represent Tarim basin north edge, 2 is Tarim basin east end and 3 is Qaidam basin.

Table 6 Lithosphere temperature of tectonic domains along the Baicheng-Da Qaidam transect

\begin{tabular}{rccc}
\hline \multirow{2}{*}{$\begin{array}{c}\text { Depth } \\
\text { km }\end{array}$} & \multicolumn{3}{c}{$T /{ }^{\circ} \mathrm{C}$} \\
\cline { 2 - 4 } & $\begin{array}{c}\text { Tarim basin } \\
\text { north edge }\end{array}$ & $\begin{array}{c}\text { Tarim basin } \\
\text { east end }\end{array}$ & $\begin{array}{c}\text { Qaidam } \\
\text { basin }\end{array}$ \\
\hline 10 & 156 & 198 & 185 \\
20 & 283 & 379 & 342 \\
30 & 372 & 523 & 453 \\
40 & 432 & 621 & 520 \\
50 & 485 & 712 & 581 \\
60 & 534 & 799 & 638 \\
70 & 581 & 884 & 691 \\
80 & 629 & 968 & 744 \\
100 & 726 & 1130 & 850 \\
150 & 970 & - & 1110 \\
\hline
\end{tabular}

\section{Discussion and conclusions}

\subsection{Discussion on uncertainty}

Discussion on uncertainty for deep seismic sounding (DSS) have been done (Jensen et al., 1999; Waldhauser et al., 1998; Zhao et al., 2006). It is difficult to quantify errors in velocity models developed by forward modeling, because the phase fitting is basically a subjective process dictated by the experience and judgment of an interpreter. The accuracy of the final crustal seismic velocity model depends on many factors. These include the correct identification of the various phases, phase fitting, the shot point interval, the receiver spacing, and, particularly for this profile, the degree of lateral variations in the thickness and seismic velocity within the sediments of the northern margin of the Tarim basin, the Altyn Tagh and the Qaidam basin. In this study, we minimized the uncertainties by adapting smaller shotreceiver spacing. We also rely on automatic imaging to reduce the bias from forward modeling. For high quality data, such as this seismic profile, seismic velocities generally have a higher precision than interface depths since seismic velocities are directly measured on the seismic sections, whereas the depths of crustal boundaries are calculated successively with velocity. In the area defined by dense ray coverage (Figure 5 ), the seismic velocities are accurate to $2 \%-5 \%$. All boundary depths (including the Moho) are accurate to $10 \%$ of the model depth. 


\subsection{The contact relation between the Tianshan and the Tarim basin}

The Tianshan orogenic belt can be divided into several segments with distinct structural features and basin-range coupling relationships (Zhao, 2005). In the western Tianshan, the Ferghana block underthrusts southward below the southern Tianshan to a depth of $200 \mathrm{~km}$. In the central Tianshan, the Tarim block underthrusts northward to a depth of $180 \mathrm{~km}$ beneath Tianshan, while the Junggar block is juxtaposed against the Tianshan across a strike-slip fault. In the eastern Tianshan, the Junggar basin underthrusts southward beneath the Tianshan, while the northern margin of the Tarim basin rolls back from the Tianshan due to the rotation of the Tarim basin. According to the focal mechanism solutions of earthquakes, this region is mostly dominated by NS-directed compression and vertical uplift, whereas strike-slip motions are confined to the faults in the southern Tianshan. Such a character of tectonic deformation is associated with crustal thickening in the Tianshan region. The thermal research indicates that the lithosphere in the northern Tarim is thicker than that of the Qaidam basin by $30-40 \mathrm{~km}$, and the Tarim lithosphere underthrusts to the Tianshan orogen. The thicker lithosphere along the northern edge of the Tarim north is associated with the subduction of cold Tarim beneath the Tianshan orogenic belt.

The passive segmentation of the Tianshan is caused by tectonic differences of the basins, since the EW tectonic variations of the basins are consistent with the segmentation of the Tianshan orogenic belt (Zhao et al., 2003a, b, c, 2004a, b).

\subsection{The special crustal structure of the Tarim basin}

The number of crustal interfaces within the Tarim basin is less than the number within the Qaidam basin by one (Figure 5). In the upper mantle, the temperature in the Qaidam basin is higher than that along the northern edge of the Tarim basin by $100^{\circ} \mathrm{C}$. By calculation, the eastern Tarim basin has a thinner lithosphere than the Qaidam basin. There are two possible explanations for this difference. One is that the two basins originated from different terrenes, which can offer information about the lithospheric structure on the ancient continent, Lordinia. The other is that the difference was produced by the formation and evolution of the unified Xinjiang ancient continent, which means that loss of middle crustal material occurred when the Tarim basin was underthrust to the Tibetan plateau (Zhao et al., 2006).

\subsection{The contact of the Tarim basin with the Altyn Tagh}

At the eastern edge of the Tarim basin, the lithospheric mantle and lower crust underthrust to the southwest, at a small angle with respect to the Altyn Tagh and NE-SW directed contraction. Such a tectonic relation is in accordance with the overthrust, uplift, and wedge-shaped mix of crust and mantle. The Moho interface beneath the Altyn Tagh and Qaidam basin is flat, implying that active deformation of this area is accommodated by plastic deformation and lateral flow (creep) of the lower crust. The North Altyn Tagh fault separates the rigid platform Tarim basin from the soft and deformable Tibetan plateau. The generation of the Altyn Tagh mountains is associated with strike-slip motions and NE-SW directed crustal shortening along the Altyn Tagh. This shortening is accommodated by the following processes: (1) Thickening caused by overthrusting of the upper crust and flow (creep) of the lower crust. (2) Underthrusting of the lithospheric mantle and the lower crust toward Altyn Tagh in the direction parallel to strike-slip deformation (SW) in the eastern Tarim basin.

The underthrust of the Tarim toward the uppermost mantle beneath the Altyn Tagh occurs in a layered way. Overthrusting occurs in the layer near the surface, whereas interlayer plunging appears in the upper and middle crust. Only the lithospheric mantle and lower crust underthrust to the uppermost mantle below the Altyn Tagh to a maximum depth of $100 \mathrm{~km}$ (Zhao et al., 2006).

\subsection{The Qaidam basin}

The basement of the Qaidam basin is "V" shape, of which both sides almost crop out on the surface (Zhao et al., 2006). In the center of the Qaidam basin, the depth of the basement is as deep as $10 \mathrm{~km}$ (Zhao, 2012). Its rigidity is less than that of the Tarim basin, as expressed by its interior deformation. The Qaidam basin exhibits a symmetrical geometry on the profile, like an intermountane basin rather than a typical foreland basin, which formed in the background of the Tibetan plateau uplift. Recent work suggests that the India-Asia collision has influenced the northern Tibetan plateau during an early phase of deformation for this event (30$40 \mathrm{Ma}$ ), leading to a rapid uplift of the Qilian (Corridor South Mountains), Altyn Tagh, and Kunlun mountains. The formation of the present Qaidam basin is associated with these rising mountains. This basin has a very deep basement and thick Mesozoic-Cenozoic sediments, with which the Tarim basin is not comparable. Because 
the development of the Qaidam basin did not begin until the Mesozoic, its formation mechanism differs from the Tarim basin. The uplift of the Tibetan plateau is differential. To the north uplift began early in the collision between India and Asia, and the collision effect was not confined to the rim. Therefore, the uplift of the plateau was not propagating from south to north as most model's.

\subsection{The differences in crustal structure of the basins in northwestern China}

The mountains Altay, Tianshan, Altyn Tagh and Kunlun, and the basins encompassed by them, such as the Junggar, the Tarim and the Qaidam, constitute the basin-range system in northwestern China. Underthrusting of basins to an orogenic belt as a result of continent-continent collision is usually expressed as an interlayer plunging and subduction but not the whole continental block moving into beneath another continent, different from ocean-continent subduction. The Junggar, Tarim and Qaidam basins have the following crustal structure features. The Junggar basin has the largest average velocity, the Tarim basin intermediate, and the Qaidam basin the least. For average thickness of crust, the Junggar basin is the least, the Tarim basin intermediate, and the Qaidam basin the largest. Beneath the Junggar basin and the Tarim basin, the top surface of the basement and Moho interface have the same geometry, implying a rigid tectonic feature, while those beneath the Qaidam basin exhibit a mirror symmetry, indicative of strong deformation within the basin.

\subsection{Conclusions}

1) Special crustal structure of the Tarim basin. The Tarim basin lacks an interface, which exists in the lower crust of the Qaidam basin, at depth $49 \mathrm{~km}$. This means that both basins have different crustal structures which result from different tectonic evolutions. One possibility is that the two basins were originated from different terrenes. Alternatively, the basins may have resulted from the formation and evolution of the unified Xinjiang ancient land. In the former case, they might contain lithospheric information of the Lordinia ancient land. In the latter case, it may raise a question whether crustal material was missing when the Tarim basin underthrust beneath the Tibetan plateau due to NS directed force.

2) Contact relation between the Tarim basin and Altyn Tagh orogen. In the eastern margin of the Tarim basin, a portion of the lower crust and lithospheric mantle underthrust toward the southwest, while contractional deformation across the Altyn Tagh fault is oriented in a NE-SW direction, both of which form at a small angles. This results in thrust faulting, uplift, and wedge-shape mixed bodies of the crust and mantle. The Altyn Tagh mountains are built due to crustal scale strike-slip deformation along the Altyn Tagh fault and by NE-SW directed crustal shortening. Such shortening is accommodated by the following two factors: (1) crustal thickening caused by upper crustal thrusting and lower crustal flow (creep), (2) underthrusting of the lower crust and lithospheric mantle in the eastern Tarim basin toward the Altyn Tagh orogen at a small angle.

3) Contact relation between the Qaidam basin and Altyn Tagh orogen. Below the Altyn Tagh mountains and Qaidam basin, the Moho discontinuity is flat, indicating that there exists no underthrust of the basin to the orogenic belt. This indicates that deformation of this region is accommodated by plastic deformation or horizontal flow (creep) of the lower crust. Because the rigidity of the Qaidam basin is smaller than that of the Tarim basin, its basement and interior have been intensely deformed during tectonic evolution.

4) The comparison among the Junggar basin, the Tarim basin and the Qaidam basin. The crust of the Junggar basin has the largest average velocity, the Tarim basin intermediate, and the Qaidam basin the least. For average thickness of crust, the Junggar basin is the least, the Tarim basin intermediate, and the Qaidam basin the largest. Beneath the Junggar basin and the Tarim basin, the top surface of the basement and Moho discontinuity have the same geometry, implying the basins are rigid tectonic feature containing crystalline basement, while those below the Qaidam basin exhibit a mirror symmetry, indicative of strong deformation within the basin.

Acknowledgements This research is financially supported by the National Key Basic Research Program (G1999043301), the National Natural Science Foundation of China (Grant Nos. 40930317 and 41104055), the SinoProbe-02 project and the NSFC Innovation Research Group Fund (Grant No. 41021001).

\section{References}

Aki K and Richards P G (2002). Quantitative Seismology: Theory and Methods. 2nd edition. University Science Books, Sausalito, CA, 700pp.

Allen M B, Vincent S J and Wheeler P J (1999). Late Cenozoic tectonics of the Kepingtage thrust zone: interactions of the Tien Shan and the Tarim basin, northwest China. Tectonics 18: 639-654.

Apperson K D and Frohlich C (1988). Sums of moment ten- 
sors for earthquakes near subduction zones. EOS Trans AGU 69: 1438.

Bally A W, Chou I M, Clayton R, Eugster H P, Kidwell S, Meckel L D, Ryder R T, Watts A B and Wilson A A (1986). Notes on sedimentary basins in China: Report of the American Sedimentary Basins delegation to the People's Republic of China. USGS Open File Report 86-327, 108.

Bendick R, Bilham R, Freymueller J T, Larson K M and Yin G H (2000). Geologic evidence for a low slip rate in the Altyn Tagh fault system. Nature 404: 69-72.

Christensen N I and Mooney W D (1995). Seismic velocity structure and composition of the continental crust: A global view. J Geophys Res 100: 9 761-9 788.

Clark M K and Royden L H (2000). Topographic ooze: Building the eastern margin of Tibet by lower crustal flow. Geology 28: 703-706.

Cowgill E, Yin A, Feng W X and Qing Z (2000). Is the North Altyn fault part of a strike-slip duplex along the Altyn Tagh fault system? Geology 28: 255-258.

Cowgill E, Yin A, Harrison T M and Wang X (2003). Reconstruction of the Altyn Tagh fault based on U-Pb geochronology: Role of back thrust, mantle sutures, and heterogeneous crustal strength in forming the Tibetan plateau. $J$ Geophys Res 108(B7): 2 346, doi: 10.1029/2002JB002080.

Frohlich C (1992). Triangle diagrams: Ternary graphs to display similarity and diversity of earthquake focal mechanisms. Phys Earth Planet Int 75: 193-198.

Gao R, Cheng X Z and Wu G J (1999). Lithospheric structure and geodynamic model of the Golmud-Ejin profile in northern Tibet. In: Macfarlane A, Sorkhabi R B and Quade J eds. Himalaya and Tibet: Mountain Roots to Mountain Tops. Boulder, Colorado, Geological Society of America, Special Paper. 328: 9-17.

Hsu K J and Chen H (1999). Geologic Atlas of China. Elsevier, Amsterdam, 1-262.

Hu S B, He L J and Wang J Y (2001). Heat flow data in the China mainland (Group 3). Chinese J Geophys 44(5): 611-626 (in Chinese with English abstract).

Jaupart C (1983). Horizontal heat transfer due to radioactivity contrasts: Causes and consequences of the linear heat flow relation. Geophys $J R$ astr Soc 75: 411-435.

Jensen S L, Janik T, Thybo H and POLONAISE Profile 1 Working Group (Keller G R, US. Team Leader) (1999). Seismic structure of the Palaeozoic Platform along POLONAISE'97 profile $P 1$ in northwestern Poland. Tectonophysics 314: 123-143.

Kind R, Yuan X, Saul J, Nelson D, Sobolev S V, Mechie J, Zhao W, Kosarev G, Ni J, Auchauer U and Jiang M (2002). Seismic images of crust and upper mantle beneath Tibet: Evidence for Eurasian plate subduction. Science 298: 1 219-1 221.

Liang S X, Sun D Z, Han Y Z and Shi S Y (1992). The terrestrial heat flow study along the geoscience transect No. IV. Chinese Science Bulletin 37(2): 143 (in Chinese with English abstract).

Liu X and Gao R (1998). The crustal structure and assembly of terranes in the Qaidam-Qilian-Beishan area, western China. Acta Geologica Sinica 72(3): 243-255.

McLennan S M, Taylor S R and Hemming S R (2005). Composition, differentiation, and evolution of continental crust: Constraints from sedimentary rocks and heat flow. In: Brown $\mathrm{M}$ and Rushmer T eds. Evolution and Differentiation of the Continental Crust. Cambridge University Press, Cambridge, 92-134.

Métivier F, Gaudemer Y, Tapponnier P and Meyer B (1998). Northeastward growth of the Tibet plateau deduced from balanced reconstruction of two depositional areas: The Qaidam and Hexi corridor basins, China. Tectonics 17: 823-842.

Meyer B, Tapponnier P, Bourjot L, Metivier F, Gaudemer Y, Peltzer G, Guo S and Chen Z (1998). Crustal thickening in Gansu-Qinghai, lithospheric mantle subduction, and oblique, strike-slip controlled growth of the Tibet plateau. Geophys J Int 135: 1-47.

Molnar P and Tapponnier P (1975). Cenozoic tectonics of Asia: Effects of a continental collision. Science 189: 419 426.

Nelson K D, Zhao W J, Brown L D, Kuo J, Che J K, Liu X W, Klemperer S L, Makovsky Y, Meissner R, Mechie J, Kind R, Wenzel F, Ni J, Nabelek J, Chen L S, Tan H D, Wei W B, Jones A G, Booker J, Unsworth M, Kidd W S F, Hauck M, Alsdorf D, Ross A, Cogan M, Wu C D, Sandvol E and Edwards M (1996). Partially molten middle crust beneath southern Tibet: Synthesis of Project INDEPTH results. Science 274: 1 684-1 688.

Peltzer G and Tapponnier P (1988). Formation and evolution of strikeslip faults, rifts, and basins during the IndiaAsia collision: An experimental approach. J Geophys Res 93: 15 085-15 117.

Peltzer G, Tapponier P and Armijo R (1989). Magnitude of the Late Quarternary left-lateral displacements along the north edge of Tibet. Science 246: 1 285-1 289.

Poupinet G, Avouac J Ph, Jiang M, Wei S, Kissling E, Herquel G, Guilbert J, Paul A, Wittlinger G, Su H and Thomas J-C (2002). Intracontinental subduction and Palaeozoic inheritance of the lithosphere suggested by teleseismic experiment across the Chinese Tian Shan. Terra Nova 14: 18-24.

Ritts B D and Biffi U (2000). Magnitude of post-Middle Jurassic (Bajocian) displacement on the central Altyn Tagh fault system, northwest China. Geol Soc Am Bull 112: $61-74$.

Ritts B D, Yue Y and Graham S A (2004). OligoceneMiocene tectonics and sedimentation along the Altyn Tagh fault, Northern Tibetan plateau: Analysis of the Xorkol, Subei, and Aksay basins. J Geol 112: 207-229. 
Royden L H (1996). Coupling and decoupling of crust and mantle in convergent orogens: Implications for strain partitioning in the crust. J Geophys Res 101(B8): 17679 17705.

Royden L H, Burchfiel B C, King R W, Wang E, Chen Z, Shen F and Liu Y (1997). Surface deformation and lower crustal flow in eastern Tibet. Science 276: 788-790.

Shao X Z, Zhang J R and Fan H J (1996). Investigation of deep structures of Earth's crust in Tarim basin by method of converted waves of earthquakes. In: Tong $\mathrm{X}$ G, Liang D G and Jia C Z eds. Progress in Research on Petroleum Geology. Science Press, Beijing, 139-148 (in Chinese).

Shen X J, Li G H, Wang J A, Deng X, Zhang W R and Yang S Z (1994). Terrestrial heat flow measurement and calculation of statistical heat flow in Qaidam basin. Chinese $J$ Geophys 37(1): 56-65 (in Chinese with English abstract).

Shen X J, Yang S Z and Shen J Y (1995). Heat flow study and analysis along the Golmud-Ejin Qi Geotransect. Acta Geophysica Sinica 38(Suppl. 1): 86-97 (in Chinese with English abstract).

Shen X J, Zhu Y Q and Shi Y L (1992). Heat flow and thermal evolution of the Tibet tectonic model research. Science in China (Series B) 22(3): 311-321.

Shen Z K, Wang M, Li Y, Jackson D D, Yin A, Dong D, and Fang P (2001). Crustal deformation along the Altyn Tagh Fault system, western China, from GPS. J Geophys Res 106: 30 607-30 621.

Song T and Wang X (1993). Structural styles and stratigraphic patterns of syndepositional faults in a contractional setting: Examples from Qaidam basin, northwestern China. Am Assoc Pet Geol Bull 77: 102-117.

Tapponnier P, Meyer B, Avouac J P, Peltzer G, Gaudemer Y, Guo S, Xiang H, Yin K, Chen Z, Cai S and Dai H (1990). Active thrusting and folding in the Qilian Shan, and decoupling between upper crust and mantle in northeastern Tibet. Earth Planet Sci Lett 97: 382-403.

Tapponnier P, Xu Z, Roger F, Meyer B, Arnaud N, Wittlinger $\mathrm{G}$ and Yang $\mathrm{J}$ (2001). Oblique stepwise rise and growth of the Tibet Plateau. Science 294: 1 671-1 677.

Vergne J, Wittlinger G, Hui Q, Tapponnier P, Poupinet G, Mei J, Herquel G and Paul A (2002). Seismic evidence for stepwise thickening of the crust across the NE Tibetan plateau. Earth Planet Sci Lett 203: 25-53.

Waldhauser F, Kissling E, Ansorge J and Mueller S (1998). Three-dimensional interface modeling with two dimensional seismic data: The Alpine crust-mantle boundary. Geophys J Int 135: 264-278.

Wang B Y, Lang Z J, Li X D, Qu X, Li T F, Huang C and Cui X (1994). Integrated Study of Geological Profiles in West Tianshan of China. Science Press, Beijing (in Chinese with English abstract).

Wang C Y, Yang Z E, Luo H and Mooney W D (2004a).
Crustal structure of the northern margin of the Tien Shan, and its tectonic implication for the $1906 M \sim 7.7$ Manas earthquake. EPSL 223: 187-202.

Wang L S (2000). Terrestrial Heat Flow, Thermal Structure and Evolution of Lithosphere in the Tarim Basin. Scientific report of Nanjing University, 65-99 (in Chinese).

Wang X F, Chen X H, Chen Z L, Chen B L, Wang L Q, Yang F and Wang K C (2004b). Geological Conditions for Mineralization and Prospect Prediction in the Altyn Tagh Area. Geological Press, Beijing, 139-148 (in Chinese).

Wang Y (2001). Heat flow pattern and lateral variations of lithosphere strength in China mainland: Constraints on active deformation. Phys Earth Planet Inter 126: 121146.

Wang Y (2006). Calculation of heat-generating element abundance of crust in mainland China using heat flow and He isotope in underground fluids. Geology of China 33(4): 920-927 (in Chinese with English abstract).

Wang Y (2007). Composition of element abundance between the exposed crust of the continent of China and the global averaged upper continental crust: Constraints on crustal evolution and some speculations. Frontiers of Earth Science in China 1(1): 69-79 (in Chinese).

Wittlinger G, Tapponnier P, Poupinet G, Mei J, Danian S, Herquel G and Masson F (1998). Tomographic evidence for localized lithospheric shear along the Altyn Tagh fault. Science 282: 74-76.

Wittlinger G, Vergne J, Tapponnier P, Farra V, Poupinet G, Jiang M, Su H, Herquel G and Paul A (2004). Teleseismic imaging of subducting lithosphere and Moho offset beneath western Tibet. Earth Planet Sci Lett 221: 117130.

Xu Z Q, Jiang M and Yang J S (1999). Mantle diapir and inward introcontinental subduction: A discuss on the mechanism of uplift of the Qinghai-Tibet plateau. Geological Society of America 328: 19-31, doi:10.1130108137-2328-0.19.

Zhao J M (2005). Lithospheric Structure and Geodynamics of Tianshan Orogenic Belt. Seismological Press, Beijing, 251pp (in Chinese with English abstract).

Zhao J M (2012). Geodynamic Conditions for Northern Margin of the Tibetan Plateau. Science Press, Beijing, 324pp (in Chinese).

Zhao J M, Cheng H G, Pei S P, Liu H B and Zhang J S (2008). Deep structure at northern margin of Tarim basin. Chinese Science Bulletin 53(10): 1 544-1 554.

Zhao J M, Fan J C and Li Z C (2003a). $Q$ value structure of geoscience transect from Korla to Jimsar and its geodynamic implication. Science in China (Series D) 46(8): 779-788.

Zhao J M, Jin Z J and Liu X (2010). A Geoscience Transect from Beicheng, Xinjiang to Da Qaidam, Qinghai, China (including a map of GGT). Science Press, Beijing, 1-73. 
Zhao J M, Jin Z J, Walter D M, Wang S X, Gao X, Tang L J, Pei S P, Liu H B and Xu Q (2012). Crustal structure of the central qaidam basin imaged by seismic wide angle reflection/refraction profiling. Tectonophysics $\mathbf{5 8 4}$ : 174-190.

Zhao J M, Li Z C, Cheng H G, Yao C L and Li Y S (2004a). Structure of lithospheric density and geomagnetism beneath the tianshan orogenic belt and their geodynamic implications. Chinese J Geophys 47(6): 1 061-1 067.

Zhao J M, Liu G D, Lu Z X, Zhang X K and Zhao G Z (2003b). Lithospheric structure and dynamic processes of the Tianshan orogenic belt and the Junggar basin. Tectonophysics 376: 199-239.

Zhao J M, Walter D M, Zhang X K, Li Z C, Jin Z J and Okaya N (2006). Crustal structure across the Altyn Tagh
Range at the northern margin of the Tibetan plateau and tectonic implications. Earth Planet Sci Lett 241: 804-814.

Zhao J M, Wang Q C, Duan Y H, Zhang X K (2004b). A finite difference study on the basement structure beneath the Tianshan Orogen. Science in China (Series D) 47(Supp. II): 16-23.

Zhao J M, Zhang X K, Deng H Z and Zhang J (2003c). Q value structure of the upper crust along the geoscience transect from Baicheng to Da Qaidam. Chinese J Geophys 46(4): 503-509 (in Chinese with English abstract). Zhu L and Helmberger D W (1998). Moho offset across the northern margin of the Tibetan plateau. Science 281: $1170-1172$. 